Argonne

ANL/ESD-16/3

\title{
Case Study - Idling Reduction Technologies for Emergency Service Vehicles
}

Energy Systems Division
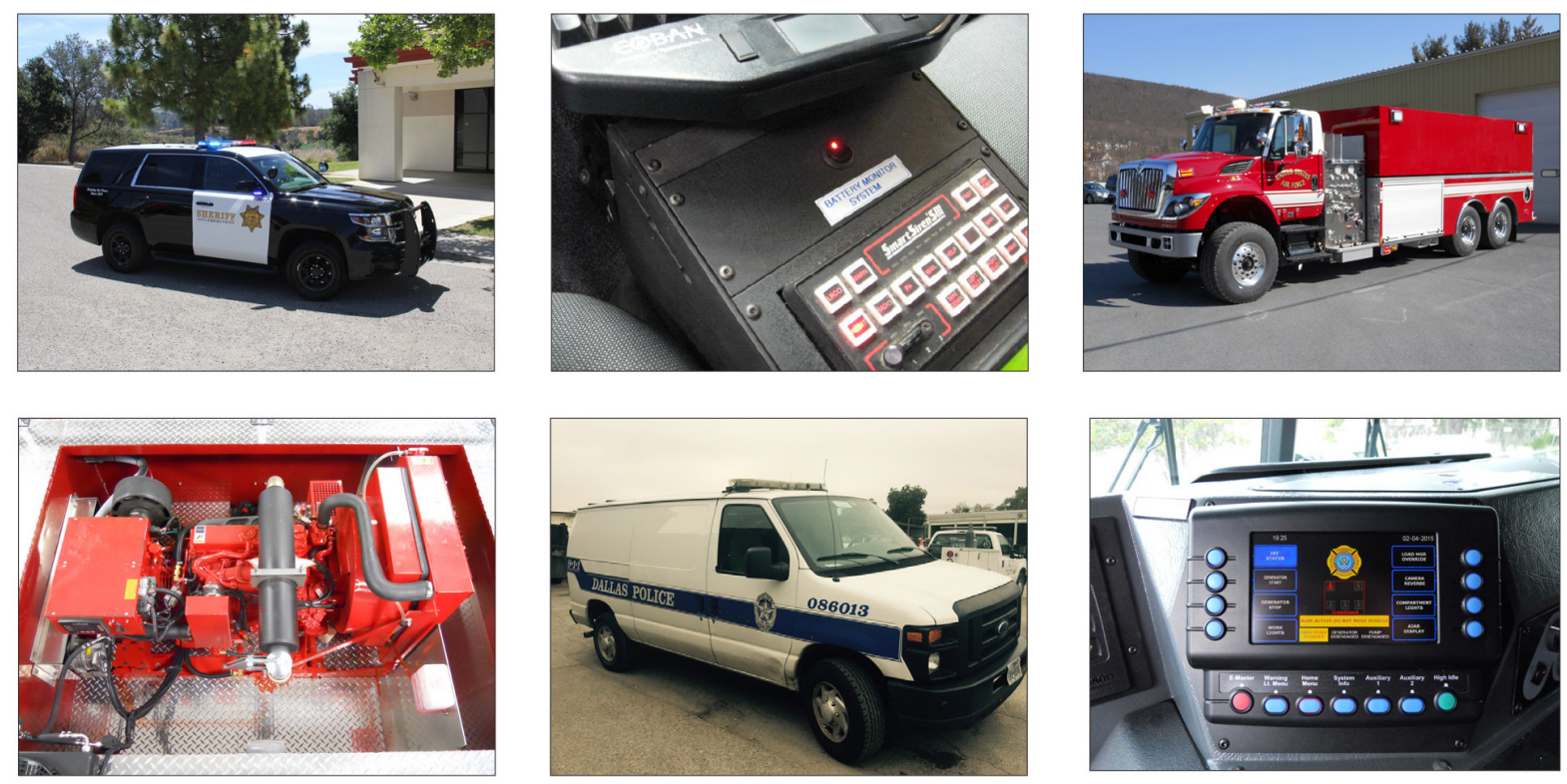
Cover photos courtesy of:

Row 1, Left to Right: Photos 1 and 2, Vermont Department of Environmental Conservation;

photo 3, United States Air Force

Row 2, Left to Right: Photo 1, United States Air Force; photo 2, City of Dallas;

photo 3, United States Air Force

\section{About Argonne National Laboratory}

Argonne is a U.S. Department of Energy laboratory managed by UChicago Argonne, LLC under contract DE-AC02-06CH11357. The Laboratory's main facility is outside Chicago, at 9700 South Cass Avenue, Argonne, Illinois 60439. For information about Argonne and its pioneering science and technology programs, see www.anl.gov.

\section{DOCUMENT AVAILABILITY}

Online Access: U.S. Department of Energy (DOE) reports produced after 1991 and a growing number of pre-1991 documents are available free via DOE's SciTech Connect (http://www.osti.gov/scitech/).

Reports not in digital format may be purchased by the public from the National Technical Information Service (NTIS):

U.S. Department of Commerce

National Technical Information Service

5301 Shawnee Road

Alexandria, VA 22312

www.ntis.gov

Phone: (800) 553-NTIS (6847) or (703) 605-6000

Fax: (703) 605-6900

Email: orders@ntis.gov

Reports not in digital format are available to DOE and DOE contractors from the Office of Scientific and Technical Information (OSTI):

U.S. Department of Energy

Office of Scientific and Technical Information

P.O. Box 62

Oak Ridge, TN 37831-0062

www.osti.gov

Phone: (865) 576-8401

Fax: (865) 576-5728

Email: reports@osti.gov

\section{Disclaimer}

This report was prepared as an account of work sponsored by an agency of the United States Government. Neither the United States Government nor any agency thereof, nor UChicago Argonne, LLC, nor any of their employees or officers, makes any warranty, express or implied, or assumes any legal liability or responsibility for the accuracy, completeness, or usefulness of any information, apparatus, product, or process disclosed, or represents that its use would not infringe privately owned rights. Reference herein to any specific commercial product, process, or service by trade name, trademark, manufacturer, or otherwise, does not necessarily constitute or imply its endorsement, recommendation, or favoring by the United States Government or any agency thereof. The views and opinions of document authors expressed herein do not necessarily state or reflect those of the United States Covernment or any agency thereof. 


\section{Case Study - Idling Reduction Technologies for Emergency Service Vehicles}

by

Russell J. Owens and Michael D. Laughlin

Energetics Incorporated for Energy Systems Division, Argonne National Laboratory

January 2016 



\section{Contents}

List of Acronyms and Abbreviations............................................................................................................ vi

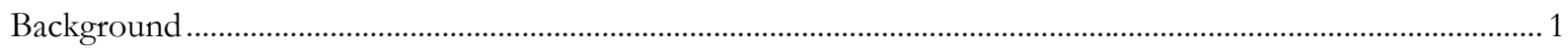

Motivation for Adopting Idling Reduction Technologies...................................................................................... 2

Environmental and Energy Benefits ............................................................................................................. 2

Governmental Initiatives.......................................................................................................................

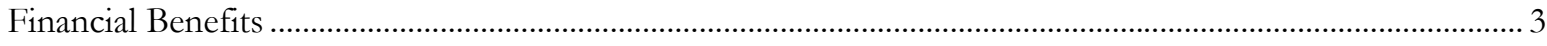

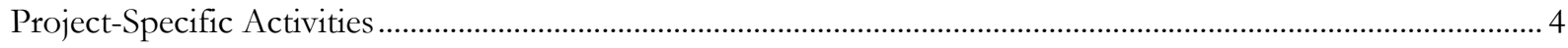

Why Emergency Vehicle Fleets Idle ............................................................................................................. 4

Technologies Deployed.......................................................................................................................... 4

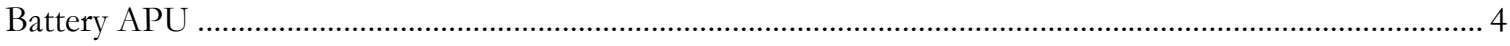

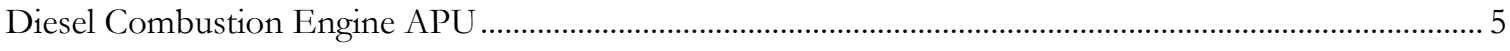

Electrified Parking Space

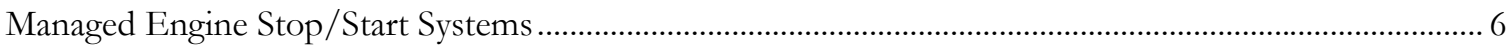

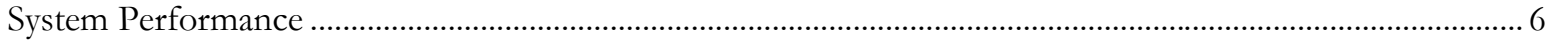

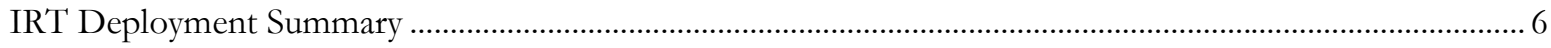

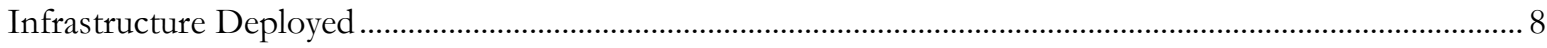

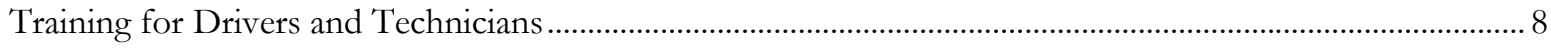

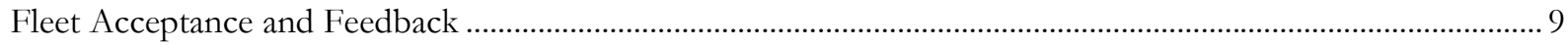

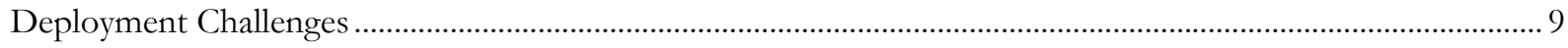

Battery APU Run Time and Battery Life ………..................................................................................... 9

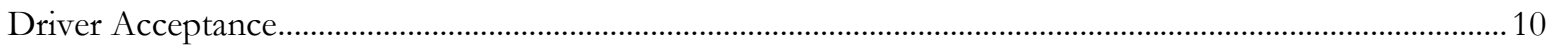

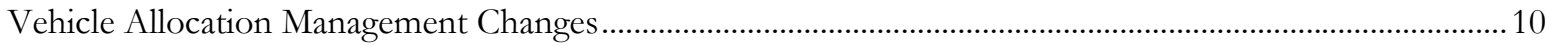

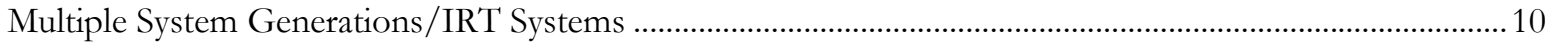

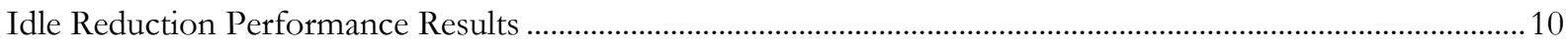

Poulsbo Fire Department (Ambulance, Using Lead-Acid Battery APU, and Fire, Using Diesel APU)........10

Austin-Travis County Emergency Medical Service (Ambulance, Using Lead-Acid Battery APU) ................11

Vermont Department of Environmental Conservation (Ambulance, Using EPS) ..........................................11

U.S. Air Force (Fire, Using Diesel APU) ....................................................................................................12

Raleigh Police Department (Police, Using Lead-Acid Battery APU) ................................................................13

City of Dallas Police Department (Police, Using Lead-Acid Battery APU) .....................................................13

County of Santa Barbara Sheriff's Office (Police, Using Managed Engine Stop/Start)..................................14

U.S. Border Patrol (Police, Using Lithium-Ion Battery APU) .............................................................................. 14 


\section{Contents (Cont.)}

Tuscaloosa Police Department (Police, Using Lithium-Ion Battery APU) .......................................................16

Lessons Learned and Future Plans ................................................................................................................... 16

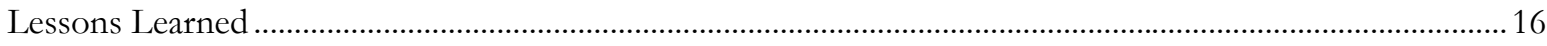

Robust Data Acquisition and Analysis ........................................................................................................ 16

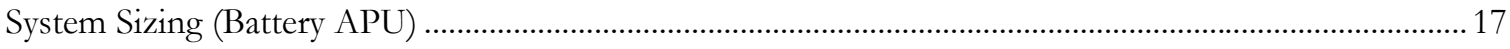

Poulsbo Fire Department (Fire, Using Diesel APU, and Ambulance, Using Lead-Acid Battery APU)...17

U.S. Air Force (Fire, Using Diesel APU) ................................................................................................. 17

Austin-Travis County Emergency Medical Service (Ambulance, Using Lead-Acid Battery APU)............17

Vermont Department of Environmental Conservation (Ambulance, Using EPS) ......................................17

Raleigh Police Department (Police, Using Lead-Acid Battery APU) ................................................................17

City of Dallas Police Department (Police , Using Lead-Acid Battery APU) .................................................. 18

County of Santa Barbara Sheriffs Office (Police, Using Managed Engine Stop/Start) .............................. 18

U.S. Border Patrol (Police, Using Lithium-Ion Battery APU) ……………………….................................. 18

Tuscaloosa Police Department (Police, Using Lithium-Ion Battery APU).................................................... 18

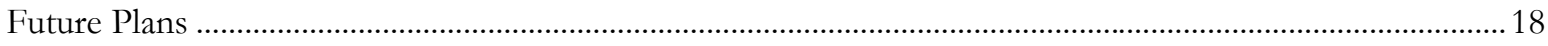

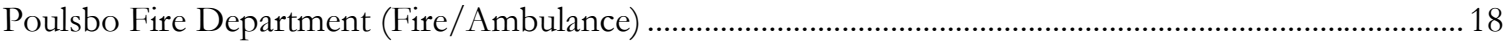

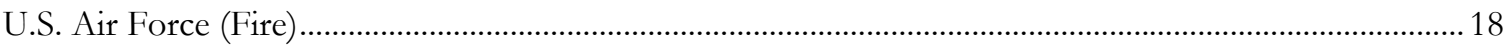

Austin-Travis County Emergency Medical Service (Ambulance)...................................................................19

County of Santa Barbara Sheriff's Office (Police)........................................................................................... 19

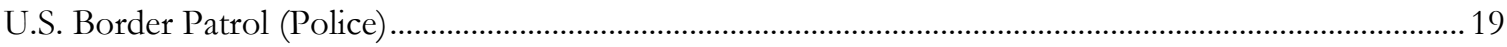

Tuscaloosa Police Department (Police) ........................................................................................................ 19

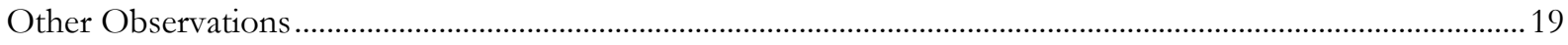

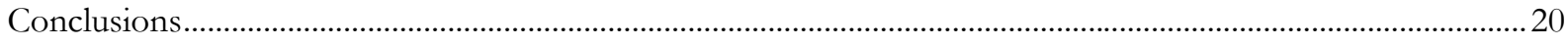

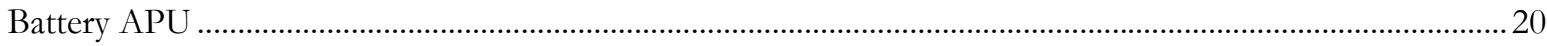

Combustion Engine APU ............................................................................................................................. 20

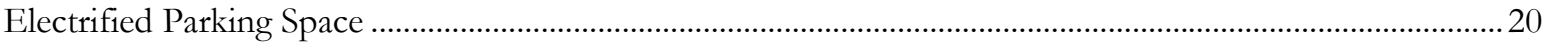

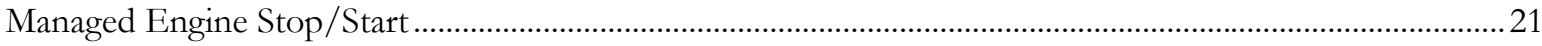

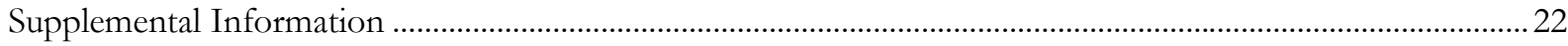

U.S. Air Force Diesel APU IRT Vehicle Procurement Specification Language...............................................22

Fleet-Specific IRT System and Fleet Details....................................................................................................... 22

Poulsbo Fire Department (Ambulance, Using Battery APU) ………………………..................................... 22

Poulsbo Fire Department (Fire, Using Diesel APU) ......................................................................................... 23 


\section{Contents (Cont.)}

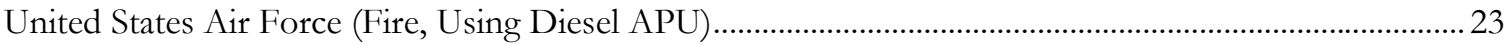

Austin-Travis County Emergency Medical Service (Ambulance, Using Lead-Acid Battery APU)............24

Vermont Department of Environmental Conservation (Ambulance, Using EPS) ......................................2 24

Raleigh Police Department (Police, Using Battery APU) ………………………………................................. 25

City of Dallas Police Department (Police, Using Battery APU) ......................................................................2 25

County of Santa Barbara Sheriff's Office (Police, Using Managed Engine Stop/Start) .............................. 25

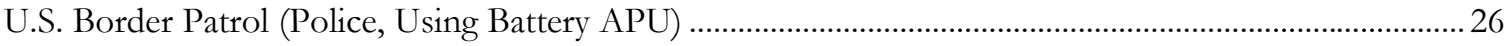

Tuscaloosa Police Department (Police, Using Battery APU) ...........................................................................26

\section{Figures}

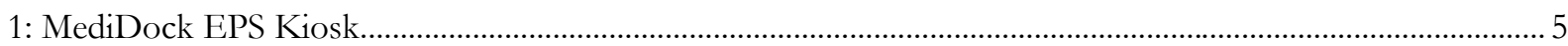

2: Ambulance connected to MediDock EPS Kiosk (HVAC and power).............................................................. 6

3: Example of APU installed on a U.S. Air Force fire truck................................................................................... 12

4: Diesel APU IRT system control panel.............................................................................................................. 12

5: Battery system installed behind front seats of paddy wagon van ....................................................................13

6: ZeroRPM IMS 60 and IMS 100 installed in load area of Chevrolet Tahoe........................................................15

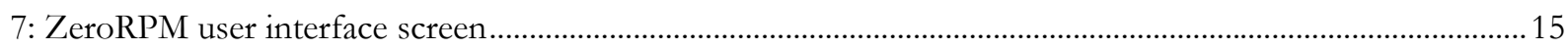

\section{Tables}

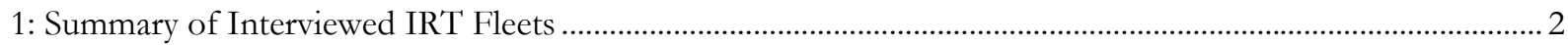

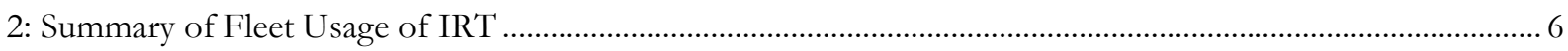




\section{LIST OF ACRONYMS AND ABBREVIATIONS}

$\begin{array}{ll}\text { A } & \text { ampere(s) } \\ \text { APCEC } & \begin{array}{l}\text { Air Force Civil Engineer Center } \\ \text { auxiliary power unit }\end{array} \\ \text { DC } & \text { direct current } \\ \text { DEC } & \begin{array}{l}\text { Department of Environmental Conservation } \\ \text { diesel particulate filter }\end{array} \\ \text { DPF } & \text { Emergency Medical Service } \\ \text { EMS } & \text { Electrified Parking Space } \\ \text { EPS } & \text { gallons per hour } \\ \text { gPh } & \text { heating, ventilation, and air conditioning } \\ \text { HVAC } & \text { idle reduction technology } \\ \text { IRT } & \text { light-emitting diode }\end{array}$




\section{Case Study - Idling Reduction Technologies for Emergency Service Vehicles}

\section{Background}

This case study explores the use of idle reduction technologies (IRTs) on emergency service vehicles in police, fire, and ambulance applications. Various commercially available IRT systems and approaches can decrease, or ultimately eliminate, engine idling. Fleets will thus save money on fuel, and will also decrease their criteria pollutant emissions, greenhouse gas emissions, and noise.

A wide range of IRT technologies are available for light-, medium-, and heavy-duty vehicles. IRTs reduce engine idling and its resulting fuel cost, emissions, and engine wear. IRTs provide an alternate (electrical) energy source to replace the idling engine that would normally power the vehicle's electrical loads. Some IRTs can also be configured to provide heat to the vehicle cabin and/or the ambulance box. IRT examples include (but are not limited to) combustion engine auxiliary power unit (APU) generator sets; battery APUs; electronic control units that manage engine operation to turn off the engine after a set time limit is reached; and electrified parking spaces (EPSs). The amount by which engine idling is reduced varies by technology, the system design, the vehicle type, and the vehicle's duty cycle.

A number of organizations have conducted studies on the use, performance, and implementation practice/challenges for IRTs for conventional vehicle fleets. However, no organization appears to have completed any studies that define IRT's applicability to, and its practical use on, emergency service vehicles (e.g., police, fire, and ambulance). Emergency service vehicles perform critical functions, so the potential use of commercially-available IRT is limited by the particular fleet's operating practice and the IRT system's design and operation. Emergency fleets are typically exempt from idle reduction regulations; however, the technology is useful for reducing fuel use and maintenance costs in many cases. This case study fills this information gap and will be a useful information source for emergency service fleets that are investigating technology options for reducing engine idling.

This case study highlights nine fleets from very different types of organizations that implemented a range of IRT solutions. The interviewed fleets included typical town/county police, fire, and ambulance fleets. Some unique Federal government fleets (fire and border patrol) were also included. Table 1 summarizes the interviewed fleets. This case study synthesizes information from the nine fleets and broadly discusses their experiences, lessons learned, and other considerations to provide a resource for deploying IRT in other emergency service vehicle fleets.

This case study was sponsored by the Clean Cities program and developed by Argonne National Laboratory and Energetics Incorporated. The fleets discussed in this case study provided critical assistance with information collection by providing access to staff to discuss their approach, experiences, and other relevant information regarding their IRT selection and use. 
Table 1: Summary of Interviewed IRT Fleets

\begin{tabular}{|c|c|c|c|c|}
\hline & Battery APU & $\begin{array}{l}\text { Diesel Combustion } \\
\text { Engine APU }\end{array}$ & $\begin{array}{l}\text { Electrified } \\
\text { Parking Space }\end{array}$ & $\begin{array}{l}\text { Managed } \\
\text { Engine } \\
\text { Stop/Start }\end{array}$ \\
\hline Fire & & $\begin{array}{l}\text { - Poulsbo Fire } \\
\text { Department (WA) } \\
\text { - U.S. Air Force } \\
\end{array}$ & & \\
\hline Ambulance & $\begin{array}{l}\text { - Austin-Travis County } \\
\text { Emergency Medical } \\
\text { Service (TX) } \\
\text { - Poulsbo Fire } \\
\text { Department (WA) }\end{array}$ & & $\begin{array}{l}\text { - Vermont } \\
\text { Department of } \\
\text { Environmental } \\
\text { Conservation } \\
\text { (VT) }\end{array}$ & \\
\hline Police & $\begin{array}{l}\text { - Raleigh Police } \\
\text { Department (NC) } \\
\text { - City of Dallas Police } \\
\text { Department (TX) } \\
\text { - U.S. Border Patrol } \\
\text { (AZ) } \\
\text { - Tuscaloosa Police } \\
\text { Department (AL) }\end{array}$ & & & $\begin{array}{l}\text { - Santa Barbara } \\
\text { County Sheriff's } \\
\text { Office (CA) }\end{array}$ \\
\hline
\end{tabular}

\section{Motivation for Adopting Idling Reduction Technologies}

In general, the fleets chose to use IRT to help meet corporate and municipal financial, environmental, and energy sustainability goals. The vehicle type did not affect the motivating factors for the fleets, so the discussion below does not differentiate the motivation by the type of vehicle or fleet.

\section{Environmental and Energy Benefits}

Improving air quality was one main common driver for IRT adoption among the fleets contributing to this study. Eliminating noise and air pollution (especially when at a hospital) was the main and initial driver for the Austin-Travis County Emergency Medical Service (EMS) (ambulance). The reason the Vermont Department of Environmental Conservation (DEC) (ambulance) funded IRT hardware implementation was to eliminate ambulance idling emissions to improve air quality and reduce air pollution and noise pollution at hospitals. Environmental/community stewardship was the primary reason the Poulsbo Fire Department (fire/ambulance) committed to invest in IRT: air quality and noise were the primary concerns. The Battalion Chief, Safety, was concerned with the air quality on scene in the field, but was also concerned to a lesser extent with air quality at the fire stations. The Poulsbo Fire Department stated that poor air quality for fire service staff and customers is a concern because of the large-displacement main vehicle engines that idle at fire and rescue scenes or at the fire station. The exhaust is at ground-level, so it can literally be "in the face" of first responders and patients at these locations. As a result, owing to high exposure rates, the Department claims that cancer rates are much higher for fire service staff than for the general population. The Department responds to many incidents involving senior citizens at nursing homes. Before IRT was implemented in the fleet, the first responders needed to idle the main engine of the emergency equipment while it was parked at the front door. Engine noise and emissions traveled into the building as a result. Noise from the idling main engine is an issue that makes communication between staff and patients very difficult. Vehicle occupants must shout to be heard over the engine.

The Raleigh Police Department (police) received grant funding from the Raleigh Sustainability Office for implementing idle reduction systems for the police fleet to contribute to Raleigh's sustainability targets. IRT is one technology the City of Dallas Police Department (police) and other regional fleets are using to help meet 
the North Central Texas Council of Governments' Clean Fleet Policy and the U.S. Environmental Protection Agency's National Ambient Air Quality Standards for ozone. The environmental and reduced energy use benefits of IRT systems provide a secondary reason why the Tuscaloosa Police Department (police) decided to adopt IRT in its police fleet.

\section{Governmental Initiatives}

The U.S. Congress has mandated reductions in fuel use from all Federal fleet vehicles (including fire equipment). The U.S. Air Force (fire) is using IRT as one technology option to meet this requirement for its fire trucks. U.S. Air Force Fire Service leadership (Fire Chief and Fire Vehicle Program Manager) at the Air Force Civil Engineer Center (AFCEC) presented the APU IRT system case to U.S. Air Force management and received approval. The AFCEC, located at Tyndall Air Force Base, leads the U.S. Air Force Fire Program, which includes approving and managing all new U.S. Air Force fire service vehicle purchases. Lowering vehicle/fleet operating costs and decreasing the environmental impact of U.S. Air Force fire service vehicles were secondary but important reasons for implementing IRT. The City of Dallas Police Department (police) used IRT as one method for complying with the North Central Texas Council of Governments Clean Fleet Policy, which seeks to reduce ozone levels. County of Santa Barbara Sheriffs Office (police) fleet management had proposed using IRT in the past, but this proposal was met with internal resistance, so was never adopted. However, a recent California Grand Jury ruling ${ }^{1}$, which was initiated by public complaints, required the County of Santa Barbara Sheriffs Office fleet to use an IRT approach to minimize idling. This ruling provided the County with the justification to implement an idle reduction program. The U.S. Border Patrol's (police) secondary interest in adopting IRT arose because the system contributes towards the fleet's response to meeting Executive Order requirements and other petroleum reduction and carbon footprint goals and targets.

\section{Financial Benefits}

Reduction in fuel use and engine wear and tear by adoption of IRT can be a significant financial incentive for adoption of the technologies, and most of the fleets in this case study cited financial benefits as a motivator. The Austin-Travis County_EMS (ambulance) saw financial benefits as a potential priority reason to adopt IRT because the chassis provider switched its maintenance interval in 2010 from a mileage-based to an enginehours-based maintenance schedule. (This example is discussed later in the Idle Reduction Performance Results section.) Decreasing the vehicle/fleet operating costs of U.S. Air Force (fire) fire service vehicles was an important reason for implementing IRT. The County of Santa Barbara Sheriff's Office (police) fleet management was motivated to use IRT to lower operating costs for several years, but IRT was ultimately implemented because of the Grand Jury ruling/mandate noted above. Reducing operating costs was also a secondary factor for the Poulsbo Fire Department (fire/ambulance). The U.S. Border Patrol's (police) primary interest in adopting IRT was for its impact on reducing maintenance, repair, and operations costs. The significant reduction in engine hours from idle avoidance is anticipated to extend the vehicles' operational life. Both the operating-cost reduction and vehicle-life extension are critical for operating the fleet more efficiently, and allow the fleet to reserve funds for other uses as overall budgets decline. Reducing fuel cost and engine wear was the primary reasons the Tuscaloosa Police Department (police) decided to adopt IRT in its police fleet.

1 Santa Barbara County (CA), Grand Jury Findings Report, "Idling Sheriffs Vehicles: It Is about Dollars and Sense," http://www.sbcgj.org/2014/IdlingSheriffsVehicles.pdf, accessed September 14, 2015. 


\section{Project-Specific Activities}

\section{Why Emergency Vehicle Fleets Idle}

All emergency vehicles are not the same, and their reasons for idling differ. Below are descriptions of the primary reasons for idling associated with each emergency vehicle application.

Ambulance - These vehicles idle while personnel are picking up patients (at homes, nursing homes, businesses, etc.), dropping off patients at hospitals, completing paperwork, and waiting for the next call.

Fire trucks - These vehicles idle while they are on scene for fire and medical emergencies. The typical call length varies by fire department, but ranges between 30 and 60 minutes. If the call is for a fire, the main engine must be run to operate the water pump (via a power take-off device) under all conditions, to deliver water to the fire. APUs have insufficient power to run the water pump continuously. However, for the interviewed fleets, roughly $80 \%$ of all calls are medical emergency calls. Medical calls do not involve the water pump, so these situations require much less power while the vehicle is stationary. The trucks are stationary while personnel are on scene providing service to patients and completing paperwork. They are required to have their scene emergency lights lit while on scene.

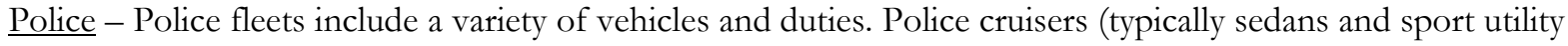
vehicles) idle primarily while officers are at a traffic stop, at the scene of an incident, watching traffic for violators, getting meals, etc. Much of the time the officers are not in the car, but the lights and other equipment must continue to operate. Officers idle the cars to run the lights, radios, and heating, ventilation, and air-conditioning (HVAC) (when allowed), and to keep the computer and communication system active and instantly available for use. There are also cases where officers will be inside a stationary vehicle (e.g., writing a report or monitoring a construction zone for speeders). These front-line cars can be used for a pair of 12-hour shifts per day. Police detective vehicles are operated differently and may spend long periods of time idling at a crime scene. Canine patrol units require the passenger cabin temperature to be maintained at all times during the work shift to keep the dog comfortable and safe. Currently, the engine must be idled to operate the HVAC system. Other applications, such as use of a U.S. Border Patrol vehicle to monitor a border, require vehicles to idle for a whole shift.

\section{Technologies Deployed}

The four IRT system categories described in this case study are 1) battery APU, 2) combustion engine APU, 3) EPS, and 4) managed engine stop/start systems. A general description of each system category is provided below. There are various designs for each system type. Specific details of particular systems used by the interviewed fleets are included in the Idle Reduction Performance Results and Supplemental Information sections.

\section{Battery APU}

The system includes a bank of deep-cycle batteries and a controller that manages the use of the stored energy. The IRT system may be always engaged, or may require the driver to flip a switch for activation. The system powers the electrical loads (e.g., emergency lights, interior lights, onboard electronic equipment such as computers, and potentially cabin HVAC) for the vehicle and the attached equipment (e.g., an ambulance body). The system operates until the main engine is restarted. The deep-cycle battery may also be charged by a shorepower electrical connection (for grid electrical power) while the vehicle is parked near an available connection. The system can also recharge the batteries by drawing power from the vehicle's alternator while the vehicle is stationary and/or while moving. Only two IRT system manufacturers (Stealth Power [or its predecessor company, Energy Xtreme] and ZeroRPM) provide products for police and ambulance fleets. (No battery APU systems for fire trucks were identified.) 
The Stealth Power/Energy Xtreme product provides electricity to power equipment. Electric HVAC is not offered. Feedback on the systems' performance and fleet results varied from positive to negative. The interviewed fleets used both early production systems (i.e., from 2007) and newer systems installed during this study (i.e., in 2015), so some of the less favorable feedback focuses largely on early production system problems or inappropriate device purchases. The systems are large and heavy because they use valveregulated lead-acid batteries. The batteries are long and slender, so the system packaging options are limited. The system dimensions and mass were a leading focus of police fleet users' criticism. One fleet could not install the systems in police cruisers, as they intended, because existing police equipment left insufficient trunk space. This fleet decided instead to install the system in a van-based paddy wagon that had more available space. Another fleet had to reconfigure the IRT system and spare tire location to improve weight balance and vehicle handling. This fleet also installed an aftermarket upgraded rear suspension to achieve the baseline vehicle's handling performance. The system mass and physical size of the Stealth Power/Energy Xtreme and other battery APU systems were not a concern on ambulances (which are larger, heavier vehicles with more available space for installing equipment).

The ZeroRPM system is modular and customizable and includes 1) a system controller that monitors the battery voltage, coolant temperature, etc., 2) lithium-ion battery(ies) (the number of modules and types [power- or energy-type] varies by application), 3) direct current (DC)-powered air-conditioning (if needed), and 4) an auxiliary DC-powered coolant pump for heat (if needed). The system starts the engine to warm the coolant if the temperature drops below a set threshold; to charge the batteries if they drop below a voltage threshold; or when the brake pedal is pressed (restart takes approximately 2 seconds). The system is lighter than lead-acid battery systems, but costs more.

\section{Diesel Combustion Engine APU}

The diesel combustion engine APU uses fuel from the main-engine fuel tank. The generator can supply the electrical loads directly, or can charge a deep-cycle battery(s). In the latter case, the vehicle electrical loads are directly powered by the battery. The IRT system engages the APU after a set time limit of engine idling (time frames of 2 to 3 minutes were typical for these systems). Systems may also require that the parking brake be engaged. The time limit and parking brake engagement ensure that the system operates only when the vehicle will be stationary but needs power for electrical loads (e.g., emergency lights, interior lights, cabin HVAC, and onboard electronic equipment such as computers). The system operates until the main engine is restarted. The deep-cycle battery may also be charged by a shorepower connection while the vehicle is parked near an available connection.

\section{Electrified Parking Space}

EPSs for emergency service vehicles are similar to those used in some shorepower-type truck stop electrification kiosks (also referred to as pedestals). All of the hardware and electrical service required to power the vehicle and provide conditioned air while it idles is installed in a fixed location. To use the system, drivers park next to the kiosk, connect the required power and HVAC equipment to the vehicle, and then turn the vehicle engine off. The EPS kiosk system is operational as long as the vehicle is connected. Figure 1 shows an example EPS kiosk. Figure 2 shows an ambulance connected to the system and using both HVAC and electrical power.

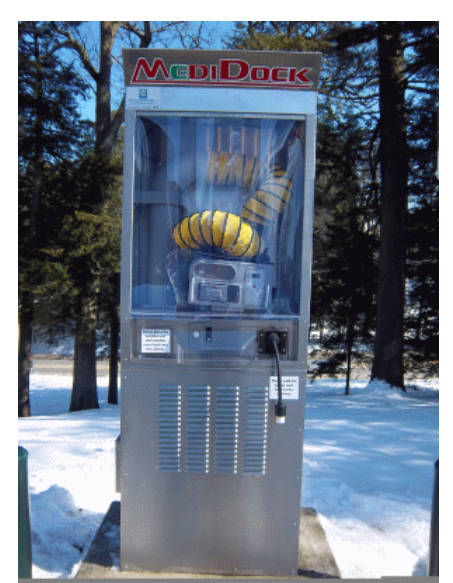

Figure 1: MediDock EPS Kiosk. Courtesy of Vermont Department of Environmental Conservation. 


\section{Managed Engine Stop/Start Systems}

Managed engine stop/start systems use an electronic controller to monitor battery charge and engine starting/stopping. Some systems use the standard deep-cycle starter battery, while others add a separate deep-cycle storage battery. The system automatically shuts down the engine after the vehicle is placed in Park and has idled for a set period of time (e.g., 2 to 3 minutes). The system monitors the battery voltage and restarts the engine when the voltage drops below a defined safe operating threshold. The engine runs for a sufficient amount of time (approximately 12 minutes, according to the one interviewed fleet using this technology) to charge the battery using the vehicle alternator. This interval does not fully

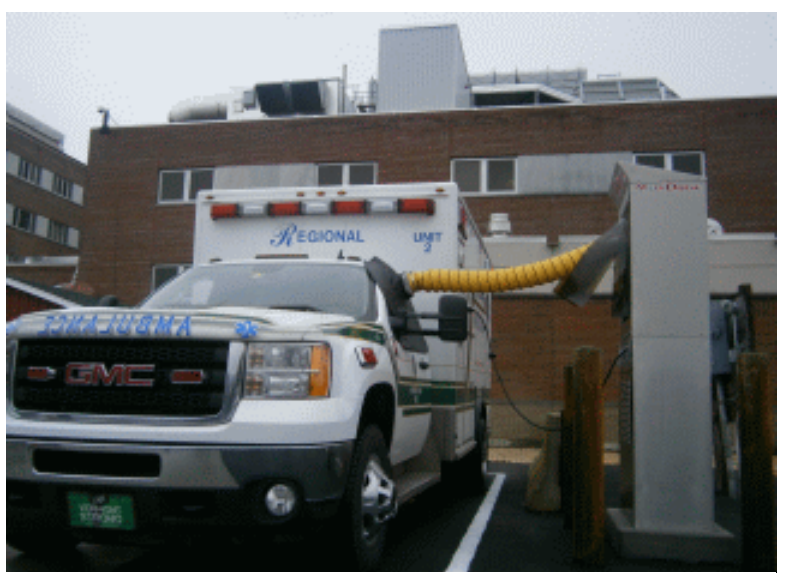

Figure 2: Ambulance connected to MediDock EPS Kiosk (HVAC and power). Courtesy of Vermont Department of Environmental Conservation. recharge the battery, so subsequent engine shutdown periods are shorter than the first. The vehicle's electrical devices are powered by the battery. The run time depends on the power draw from the electrical devices being used.

\section{System Performance}

Quantifying the system performance was difficult because each fleet has a different duty cycle and method for determining performance. Some IRT manufacturers offered a data collection and reporting service, but fleets' impressions were that the accuracy of some of these services was not high. Developing a clear method in the industry for quantifying the data collection, data analysis, and data presentation is suggested to provide fleets with a common set of information about IRT technologies and manufacturers to determine which system(s) suit their application.

\section{IRT Deployment Summary}

This case study includes a wide range of emergency service vehicle types (police, fire, and ambulance) and types of IRT. Table 2 provides a high-level summary of the vehicle types, IRT systems, functions, and application to new or in-service vehicles.

\section{Table 2: Summary of Fleet Usage of IRT}

\begin{tabular}{|c|c|c|c|c|c|c|c|}
\hline $\begin{array}{l}\text { Fleet } \\
\text { Type }\end{array}$ & $\begin{array}{l}\text { Fleet } \\
\text { Name }\end{array}$ & $\begin{array}{l}\text { IRT } \\
\text { Type }\end{array}$ & $\begin{array}{c}\text { Functions Fleet Requires } \\
\text { While Stationary }\end{array}$ & $\begin{array}{l}\text { Functions } \\
\text { IRT } \\
\text { Provides }\end{array}$ & $\begin{array}{c}\text { IRT } \\
\text { Electric } \\
\text { HVAC } \\
\text { Available? }\end{array}$ & $\begin{array}{c}\text { IRT } \\
\text { Electric } \\
\text { HVAC } \\
\text { Selected? }\end{array}$ & $\begin{array}{l}\text { New or } \\
\text { Retrofit }\end{array}$ \\
\hline Fire & $\begin{array}{l}\text { Poulsbo } \\
\text { Fire } \\
\text { Dept. } \\
\text { (WA) }\end{array}$ & $\begin{array}{l}\text { Diesel } \\
\text { APU }\end{array}$ & $\begin{array}{l}\text { Engine stop while vehicle is } \\
\text { stationary; electric power } \\
\text { for lights, radios, and other } \\
\text { electrical equipment }\end{array}$ & $\begin{array}{c}\text { Same, except } \\
\text { HVAC } \\
\text { because } \\
\text { baseline } \\
\text { vehicle } \\
\text { already has }\end{array}$ & No & $\mathrm{n} / \mathrm{a}$ & $\begin{array}{l}\text { New, } \\
\text { retrofit } \\
\text { is an } \\
\text { option }\end{array}$ \\
\hline Fire & $\begin{array}{l}\text { U.S. Air } \\
\text { Force } \\
\text { Civil } \\
\text { Engineer } \\
\text { Center }\end{array}$ & $\begin{array}{c}\text { Diesel } \\
\text { APU }\end{array}$ & $\begin{array}{l}\text { Engine stop while vehicle is } \\
\text { stationary; electric power } \\
\text { for lights, radios, and other } \\
\text { electrical equipment }\end{array}$ & $\begin{array}{c}\text { Same, except } \\
\text { HVAC } \\
\text { because } \\
\text { baseline } \\
\text { vehicle } \\
\text { already has }\end{array}$ & No & $\mathrm{n} / \mathrm{a}$ & $\begin{array}{l}\text { New, } \\
\text { retrofit } \\
\text { is an } \\
\text { option }\end{array}$ \\
\hline
\end{tabular}


Table 2: (Cont.)

\begin{tabular}{|c|c|c|c|c|c|c|c|}
\hline $\begin{array}{l}\text { Fleet } \\
\text { Type }\end{array}$ & $\begin{array}{l}\text { Fleet } \\
\text { Name }\end{array}$ & $\begin{array}{l}\text { IRT } \\
\text { Type }\end{array}$ & $\begin{array}{c}\text { Functions Fleet Requires } \\
\text { While Stationary }\end{array}$ & $\begin{array}{l}\text { Functions } \\
\text { IRT } \\
\text { Provides }\end{array}$ & $\begin{array}{c}\text { IRT } \\
\text { Electric } \\
\text { HVAC } \\
\text { Available? }\end{array}$ & $\begin{array}{l}\text { IRT } \\
\text { Electric } \\
\text { HVAC } \\
\text { Selected? }\end{array}$ & $\begin{array}{l}\text { New or } \\
\text { Retrofit }\end{array}$ \\
\hline $\begin{array}{l}\text { Ambu- } \\
\text { lance }\end{array}$ & $\begin{array}{l}\text { Poulsbo } \\
\text { Fire } \\
\text { Dept. } \\
\text { (WA) }\end{array}$ & $\begin{array}{l}\text { Lead- } \\
\text { Acid } \\
\text { Battery } \\
\text { APU }\end{array}$ & $\begin{array}{l}\text { Engine stop while vehicle is } \\
\text { stationary; electric power for } \\
\text { lights, radios, HVAC for } \\
\text { ambulance body, and other } \\
\text { electrical equipment }\end{array}$ & $\begin{array}{c}\text { Same, } \\
\text { except } \\
\text { HVAC } \\
\text { because } \\
\text { baseline } \\
\text { vehicle } \\
\text { already has } \\
\end{array}$ & No & $\mathrm{n} / \mathrm{a}$ & $\begin{array}{l}\text { New, } \\
\text { retrofit } \\
\text { is an } \\
\text { option }\end{array}$ \\
\hline $\begin{array}{l}\text { Ambu- } \\
\text { lance }\end{array}$ & $\begin{array}{l}\text { Austin- } \\
\text { Travis } \\
\text { County } \\
\text { EMS } \\
\text { (TX) }\end{array}$ & $\begin{array}{l}\text { Lead- } \\
\text { Acid } \\
\text { Battery } \\
\text { APU }\end{array}$ & $\begin{array}{l}\text { Engine stop while vehicle is } \\
\text { stationary; electric power for } \\
\text { lights, radios, HVAC for } \\
\text { ambulance body, and other } \\
\text { electrical equipment }\end{array}$ & $\begin{array}{c}\text { Same, } \\
\text { except } \\
\text { HVAC } \\
\text { because } \\
\text { baseline } \\
\text { vehicle } \\
\text { already has }\end{array}$ & No & $\mathrm{n} / \mathrm{a}$ & $\begin{array}{l}\text { New, } \\
\text { retrofit } \\
\text { is an } \\
\text { option }\end{array}$ \\
\hline $\begin{array}{l}\text { Ambu- } \\
\text { lance }\end{array}$ & $\begin{array}{l}\text { Vermont } \\
\text { DEC } \\
\text { (VT) }\end{array}$ & EPS & $\begin{array}{l}\text { Engine stop while vehicle is } \\
\text { stationary; electric power for } \\
\text { lights, radios, HVAC for } \\
\text { ambulance body, and other } \\
\text { electrical equipment }\end{array}$ & Same & Yes & Yes & $\mathrm{n} / \mathrm{a}$ \\
\hline Police & $\begin{array}{l}\text { Raleigh } \\
\text { Police } \\
\text { Dept. } \\
\text { (NC) }\end{array}$ & $\begin{array}{l}\text { Lead- } \\
\text { Acid } \\
\text { Battery } \\
\text { APU }\end{array}$ & $\begin{array}{l}\text { Engine stop while vehicle is } \\
\text { stationary; electric power for } \\
\text { lights, radios, and other } \\
\text { electrical equipment }\end{array}$ & Same & No & No & $\begin{array}{l}\text { Retrofit, } \\
\text { new is } \\
\text { an } \\
\text { option }\end{array}$ \\
\hline Police & $\begin{array}{l}\text { City of } \\
\text { Dallas } \\
\text { Police } \\
\text { Dept. } \\
\text { (TX) }\end{array}$ & $\begin{array}{l}\text { Lead- } \\
\text { Acid } \\
\text { Battery } \\
\text { APU }\end{array}$ & $\begin{array}{l}\text { Engine stop while vehicle is } \\
\text { stationary; electric power for } \\
\text { lights, radios, HVAC, and } \\
\text { other electrical equipment }\end{array}$ & $\begin{array}{l}\text { Same, } \\
\text { except for } \\
\text { HVAC }\end{array}$ & Yes & No & $\begin{array}{l}\text { Retrofit, } \\
\text { new is } \\
\text { an } \\
\text { option }\end{array}$ \\
\hline Police & $\begin{array}{l}\text { U.S. } \\
\text { Border } \\
\text { Patrol } \\
\text { (AZ) }\end{array}$ & $\begin{array}{l}\text { Lithium- } \\
\text { Ion } \\
\text { Battery } \\
\text { APU }\end{array}$ & $\begin{array}{l}\text { Engine stop while vehicle is } \\
\text { stationary; electric power for } \\
\text { lights, radios, HVAC, and } \\
\text { other electrical equipment }\end{array}$ & Same & Yes & Yes & $\begin{array}{l}\text { New, } \\
\text { retrofit } \\
\text { is an } \\
\text { option }\end{array}$ \\
\hline Police & $\begin{array}{l}\text { Tusca- } \\
\text { loosa } \\
\text { Police } \\
\text { Depart- } \\
\text { ment } \\
\text { (AL) }\end{array}$ & $\begin{array}{l}\text { Lithium- } \\
\text { Ion } \\
\text { Battery } \\
\text { APU }\end{array}$ & $\begin{array}{l}\text { Engine stop while vehicle is } \\
\text { stationary; electric power for } \\
\text { lights, radios, HVAC (cooling } \\
\text { and heating), and other } \\
\text { electrical equipment }\end{array}$ & Same & Yes & Yes & $\begin{array}{l}\text { New, } \\
\text { retrofit } \\
\text { is an } \\
\text { option }\end{array}$ \\
\hline Police & $\begin{array}{c}\text { Santa } \\
\text { Barbara } \\
\text { County } \\
\text { Sheriff's } \\
\text { Office } \\
\text { (CA) }\end{array}$ & $\begin{array}{l}\text { Managed } \\
\text { Engine } \\
\text { Stop/ } \\
\text { Start } \\
\text { Systems }\end{array}$ & $\begin{array}{l}\text { Engine stop while vehicle is } \\
\text { stationary; electric power for } \\
\text { lights, radios, and other } \\
\text { electrical equipment }\end{array}$ & Same & No & $\mathrm{n} / \mathrm{a}$ & Retrofit \\
\hline
\end{tabular}




\section{Infrastructure Deployed}

Battery APU systems may or may not require a shorepower electrical connection (e.g., 110 VAC 15-30 amps [A] service). If used, the shorepower connection charges the battery and operates any onboard systems that must remain active while the vehicle is parked. The required shorepower power capacity (e.g., $20 \mathrm{~A}$ or $30 \mathrm{~A}$ ) depends on the battery energy capacity, how long the vehicle is plugged in, and the onboard electrical loads that must remain active while it is plugged in. The fire trucks and ambulances for the interviewed fleets all had existing electrical plugs for shorepower. In some cases, the electrical power (i.e., service amperage) had to be increased to provide sufficient power to recharge the batteries in an appropriate amount of time while continuing to power the electrical loads of the vehicle (such as HVAC systems, refrigerators, and intravenousfluid warmers for ambulances). For the diesel APU fire engine system, shorepower also powers a block heater to keep the main engine oil warm.

For some applications (e.g., front-line police cruisers in heavy/constant use), vehicles are not stationary for enough time to recharge the battery with a plug-in connection. The battery may also become fully discharged before the vehicle's shift is over. In these cases, the battery is recharged with an alternator. Depending on the size of the system, the stock alternator may have sufficient capacity to recharge the batteries. Otherwise, either an alternator with uprated power output or a secondary alternator can be used to provide the necessary power.

The EPS IRT option (i.e., the MediDock) requires only infrastructure, specifically, a kiosk with HVAC and electric power. No vehicle-mounted equipment is required to use EPS. This approach was only used by interviewees for ambulance fleets while parked at hospitals.

\section{Training for Drivers and Technicians}

The Austin-Travis County EMS (ambulance) trains new drivers on how to operate the system during their normal new-employee equipment training. Ongoing staff training is accomplished by including a periodic reminder to drivers of the systems' purpose and benefits and how to operate them.

The relevant staff at hospitals participating in the Vermont DEC's EPS projects were trained when the kiosks were installed. Ambulance drivers who are unfamiliar with how to operate the system are instructed by other ambulance drivers, by hospital staff, or by viewing an online training video.

Each U.S. Air Force (fire) vehicle has a Technical Manual (for operators) and a Maintenance Manual (for maintenance providers). The U.S. Air Force requires vehicle manufacturers to provide onsite training (both for operators and for maintenance providers) when a new vehicle is delivered. The U.S. Air Force requires that new drivers of any vehicle pass a formal course and test for each vehicle type to prove they are competent to operate it. The courses and tests are custom-designed for each vehicle and are posted on the U.S. Air Force Virtual Learning Center so they are accessible to all U.S. Air Force locations at any time. Using multiple truck manufacturers and IRT manufacturers increases training costs (for material production and staff time).

Raleigh Police Department (police) drivers were trained by the Police Service Center staff when the systems were first installed. Maintenance staff were trained for installations and all were able to quickly understand how the system functioned and was operated. (An electronic copy of both training presentations was given to the fleet to use for subsequent training.)

City of Dallas Police Department (police) drivers and maintenance staff were given a brief training class by the IRT manufacturer. 
The County of Santa Barbara Sheriff's Office (police) developed a driver's training class that consists of a 9-page presentation and a hands-on system demonstration.

U.S. Border Patrol drivers were trained by the IRT manufacturer on how the system operates. The maintenance staff were trained to troubleshoot/repair the system.

\section{Fleet Acceptance and Feedback}

The Poulsbo Fire Department (fire, using diesel APU, and ambulance, using lead-acid battery APU) worked interactively with the system developer (Cummins Northwest) to develop and refine both systems. As a result, vehicles were equipped with different generations of both systems as they evolved. This increased driver/maintenance training requirements and caused some user confusion related to how each system worked. The fleet believes that this will not be an issue when all trucks are equipped with the final system version, which will be consistent across vehicles. Not all Austin-Travis County EMS (ambulance, using leadacid battery APU) ambulances have the same-generation system, since the system was evolving over the deployment time frame. As a result, there was some uncertainty among fleet personnel about operations in two areas: 1) which ambulances have the battery APU and which do not, and 2) which engines need to be turned off to enable the system to start. The fleet noted that this issue will be eliminated once the same system is used on all ambulances. Each hospital participating in the Vermont DEC (ambulance, using EPS) program has an anti-idling policy; however, each hospital is responsible for its own enforcement, so the actual enforcement is inconsistent. Multiple ambulance companies serve the hospitals, and each company has its own policy and interest concerning idle reduction. Some drivers do not like to/will not use the system. Some will not use the system if they think they will only be parked for a short time. City of Dallas Police Department (police, using lead-acid battery APU) drivers were told to use the systems, but they stopped using them after the systems experienced problems and ultimately ceased to work entirely. The County of Santa Barbara Sheriff's Office (police, using managed engine stop/start) has nearly 100\% use compliance because the systems' use was prompted and required by a California Grand Jury ruling. Both the U.S. Border Patrol (police, using lithium-ion battery APU) and the Tuscaloosa Police Department (police, using lithium-ion battery APU) have experienced good driver acceptance of the system in general, but noted that some staff require additional training to reinforce why it is being used and what the system does for the fleet.

\section{Deployment Challenges}

\section{Battery APU Run Time and Battery Life}

Two fleets (City of Dallas Police Department and Raleigh Police Department) that used lead-acid battery systems noted that the real-world discharge time was much shorter than projected by the IRT manufacturer. This finding can be at least partially explained by the fact that these fleets require a higher average power draw than assumed by the IRT manufacturer (this was a common occurrence). Similarly, several fleets noted that the real-world useful life (i.e., years of use) of batteries was much shorter than projected by the IRT manufacturer. The battery pack replacement cost can be as much as $\$ 1,800$ to $\$ 7,500$ or higher (depending on the battery capacity and battery chemistry [e.g., lead-acid or lithium-ion]). In several cases, the poor system performance and high battery replacement cost of lead-acid battery systems resulted in the fleet removing the systems from vehicles. 


\section{Driver Acceptance}

Driver acceptance appeared to be high overall, but some fleets experienced challenges. The use of the IRT for some fleets was required by legislation. For others, the system was designed to operate automatically to maximize fuel savings (while maintaining safety).

\section{Vehicle Allocation Management Changes}

Fleets that assign a vehicle to staff at the beginning of a shift (e.g., police) assign the first available vehicle. This approach works well when all of the vehicles are identically equipped. To maximize the IRT system use (and the resulting cost savings), fleet managers whose fleets include multiple sub-fleets (e.g., with different IRT types/levels of vehicle configurations) must manage the fleets differently to maximize cost savings. In these cases, fleet managers must adapt their vehicle allocation processes to assign the right vehicle type to staff to maximize the petroleum and cost savings. This is not necessarily a challenge, but rather a factor that must be addressed when the vehicles are introduced into the fleet.

\section{Multiple System Generations/IRT Systems}

Several fleets mentioned that different vehicles were equipped with different systems (or different generations of the same system); many were in early development and deployment stages. In these cases, IRT manufacturers were improving systems during the deployment across the fleet. This led to driver confusion and frustration, especially for shared vehicles, because the operation and functionality of the systems differed. This situation led to decreased driver acceptance and the systems not achieving their maximum potential petroleum savings. It also increased driver training requirements. The fleets expect that driver acceptance will improve once all vehicles are equipped with the same system version.

In some cases, IRT system manufacturers reverse engineer the vehicle's control software to enable the IRT system to control vehicle functions (e.g., turn the engine off/on). This process must be done for each vehicle model, for each model year. The IRT control software must be re-evaluated and updated to ensure the IRT system functions properly. The IRT system software updating process becomes complicated when fleets have many vehicle models, model years, and IRT system generations/software versions. A more complete discussion of these issues is located in the "Fleet Acceptance and Feedback" section above. This need to reprogram systems may lead to increased costs and complexity to "re-chassis" systems onto newer vehicles (i.e., reinstall them onto a new base vehicle chassis at the original chassis' end-of-life).

\section{Idle Reduction Performance Results}

In general, the fleets included in this case study did not collect sufficient data or perform analyses to accurately quantify the petroleum use, greenhouse gas emissions, and operating-cost reduction performance of the IRT systems. In many cases, only estimated average performance figures were available. The bestavailable information collected in this case study research is presented below. Additional useful information that does not specifically reference sections of this report is located in the Supplemental Information section at the end of this report.

\section{Poulsbo Fire Department (Ambulance, Using Lead-Acid Battery APU, and Fire, Using Diesel APU)}

The first installations of the fully developed lead-acid battery APU (ambulance) and diesel APU (fire) systems began in 2012, so the systems have been in service for a maximum of 3.5 years. The complete installed battery APU (ambulance) system cost is approximately $\$ 12,000$, or roughly $5 \%$ of the complete ambulance cost. The complete installed diesel APU (fire) system cost is approximately $\$ 30,000$, or between $0.03 \%$ and $5 \%$ of the complete fire truck cost. The battery APU (ambulance) system eliminates diesel fuel use when the 
ambulance is stationary, and can provide power for hotel loads for 6 to 8 hours on a full charge. The diesel APU (fire) reduces diesel fuel use from 1.3 gallons per hour (gph) for the main engine to $0.3 \mathrm{gph}$ for the APU, a $77 \%$ reduction. The per-vehicle fuel use reductions vary by vehicle type, but 700 hours of mainengine idling were eliminated per year for a typical fire pumper truck.. Washington State fully funded these systems, so achieving a certain payback time was not a factor for this fleet. A rough estimate using 700 hours of avoided idling per year, 1 gallon saved per hour, and $\$ 2.50$ per gallon of diesel results in an annual savings of $\$ 1,750$, which equates to a simple payback period of 17.2 years for the fire trucks. Maintenance savings (e.g., reduced oil change frequency) will improve this figure.

The fleetwide (five ambulances and five fire pumper trucks) IRT system installation is estimated to have reduced annual fuel use by roughly $5.6 \%$. The fuel savings alone equate to a $\$ 9,000$ annual fleet cost reduction. The fleet was pleased with this result.

The fleet indicated that the secondary operating-cost saving benefits for both APU systems may be more substantial than the fuel savings. These secondary benefits include 1) $50 \%$ fewer engine oil changes (one per year instead of two per year) because the oil lasts longer, and 2) significantly lower engine wear and tear (engine-hour-related), which is predicted to extend the vehicle life. The fleet is currently working to validate the life-cycle cost impact of these secondary benefits.

Both the lead-acid battery APU and diesel APU systems and the intact ambulance box are expected to be rechassised when the base vehicle's useful life reaches its end. This procedure extends the system life and increases the lifetime savings, and is anticipated to be done at least one time.

\section{Austin-Travis County Emergency Medical Service (Ambulance, Using Lead-Acid Battery APU)}

The Austin-Travis County EMS analyzed collected operational data early in the project to understand the fleet's duty cycle, specifically idling. This rough data analysis showed an average of 10-15 patient transports, including approximately eight hours of idling, per day. The fleet EMS's operating costs for its new Ford ambulances dramatically increased in 2010 when Ford switched from a mileage-based to an engine-hoursbased maintenance schedule. This switch meant that ambulances were having their oil changed every 7-10 days at a cost of $\$ 575$ (parts and labor) plus the cost of out-of-service time. The Stealth Power lead-acid battery APUs reduced engine oil changes by $67 \%$; from 36 per year $(\$ 20,700)$ to 12 per year $(\$ 6,900)$. This is a $\$ 13,800$ annual savings on oil changes alone. The fleet estimates an average of eight hours of idling per day, so assuming 365-days-per-year operation, a savings of $0.7 \mathrm{gph}$ at $\$ 2.50$ per gallon equals $\$ 5,100$ of annual fuel savings. Battery replacement(s) factor significantly into the system's return on investment. The battery APU manufacturer estimates battery life to be between three and five years. Many of Austin's vehicles are three years old. The 6.0-kWh battery pack will cost approximately $\$ 7,500$ to replace. As is the case for the Poulsbo Fire Department, the battery APU and the intact ambulance box are expected to be rechassised when the base vehicle's useful life reaches its end. The battery APU system is anticipated to be re-chassised twice. This measure significantly extends the system life and increases the lifetime savings. The installed system cost is between $\$ 20,000$ and $\$ 25,000$, so the simple system payback period from reduced maintenance and fuel costs is between 1.1 and 1.3 years. The high oil-cost savings for this fleet results in the net effective costs remaining favorable in all later years, even accounting for battery replacements every three years.

\section{Vermont Department of Environmental Conservation (Ambulance, Using EPS)}

The Vermont DEC has had some data collection challenges. The EPS approach requires that data be collected on the infrastructure side. The MediDock EPS kiosk supplies conditioned air via an electrically powered HVAC system and electric power via the shorepower electrical connections. Each ambulance can 
use one or both of these services, depending on its needs. The HVAC system has an hour meter to track total HVAC usage, but the early-model kiosk used in these projects does not have a method for tracking usage of electrical power via the shorepower electrical connection. As a result, hospitals cannot accurately track total system use if only electrical power is used. There is also no method for determining ambulance-hours of kiosk use vs. ambulance-hours of idling, so there is no method for quantifying the system utilization.

Additionally, the operator avoidance factor must be considered. Avoidance occurs when an ambulance operator shuts down the engine to comply with the hospital's idling policy and determines that the use of the kiosk is not necessary at that time. Anecdotal information indicates that the kiosks are used frequently and that the EPSs are not capacity-constrained.

\section{U.S. Air Force (Fire, Using Diesel APU)}

The U.S. Air Force fleet includes nearly 1,900 vehicles. The diesel APU IRT system is used on roughly 900 structural, rescue, and water tanker fire-fighting vehicles. All U.S. Air Force fire trucks use diesel APUs. Historically, these systems were manually-controlled by the operator, so the APU may not have been engaged (and the main engine turned off) at every opportunity to minimize idling. However, all new U.S. Air Force fire truck purchases are equipped with automatically controlled diesel APU IRT systems that maximize APU use and thus minimize idling fuel use. Figure 3 shows an example of an installed APU. Figure 4 shows the system control panel for one diesel APU system. As of June 2015, the U.S. Air Force fleet included 126 fire trucks equipped with automaticallycontrolled diesel APU IRT systems. (The trucks were

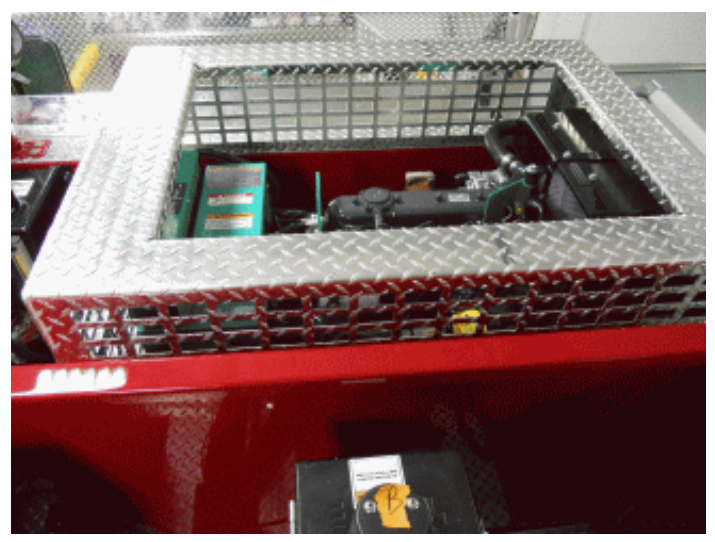

Figure 3: Example of APU installed on a U.S. Air Force fire truck. Courtesy of United States Air Force, HQ Air Force Civil Engineer Center (AFCEC)/CXF, Tyndall Air Force Base.

fielded between 2012 and 2015, when new trucks were purchased.) These diesel APU systems use 0.25 gph compared to $1.25 \mathrm{gph}$ for the main engine. This is a significant 1.0-gph $(80 \%)$ fuel savings. The U.S. Air Force has calculated that the system saves more than $\$ 2,600$ per vehicle annually in fuel costs alone, for approximately 1,000 hours of idling. The incremental system cost is approximately $\$ 3,000$ above a standard manually controlled fire truck APU system. The fuel-cost savings result in a 14-month (1.15-year) simple payback period. (The payback will be faster and return on investment will be higher when main-engine maintenance savings are included.) As a result of the low initial cost and fast payback, all new U.S. Air Force fire trucks are being equipped with the integrated IRT system.

The useful life for U.S. Air Force fire trucks is 20 years, so the projected lifetime fleet fuel-only savings for the current 126 -truck fleet is more than $\$ 6.5$ million at current fuel prices. The lifetime fuel-only savings of the entire 900 -vehicle fleet (once the system is fully deployed) is estimated to be more than \$46.8 million.

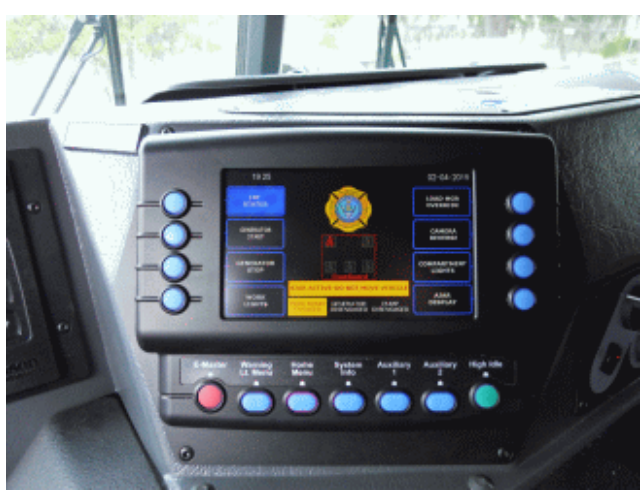

Figure 4: Diesel APU IRT system control panel. Courtesy of United States Air Force, HQ Air Force Civil Engineer Center (AFCEC)/CXF, Tyndall Air Force Base. 


\section{Raleigh Police Department (Police, Using Lead-Acid Battery APU)}

The Raleigh Police Department has installed 2.0-kWh Energy Xtreme lead-acid battery APU systems on 29 of the Department's police cruisers. Grant funds provided by the Raleigh Sustainability Office paid for the systems and one year of the manufacturer's system usage data and reporting service. Because of this funding method, system payback was not a primary project metric. However, understanding the system's costeffectiveness for projecting payback for potential future Department-funded systems was a project goal.

The hardware cost for each system was $\$ 3,995$. Energy Xtreme staff trained Raleigh Police Department maintenance technicians over 1-2 days to install the system. Department mechanics took between 4 and 8 hours to perform each system installation. All 29 systems were operational by early 2012 .

The manufacturer estimated a run time of between 4 and 6 hours at a common police vehicle electrical load of 20 A. The Raleigh Police Department's cruiser equipment draws roughly $45 \mathrm{~A}$, so a full charge lasted only 2-3 hours. This was a disappointment to the fleet because it decreased the system's fuel-savings performance. (This disappointment was a common occurrence among the interviewed fleets, as described in more detail in the Lessons Learned section.) However, the shorter run time should have been anticipated because of the vehicle's higher electrical load. Battery useful life was also an issue with the systems. The manufacturer quoted a 5- to 7-year battery life, but the Department observed battery lives between 2 and 3 years, or roughly double the expected replacement rate. The fleet did not replace any batteries, but a few systems were removed once the battery needed to be replaced.

The manufacturer provided a system usage data and reporting service to the fleet for the first year to assess and report on the system's benefits. The Department had questions regarding the accuracy of this service's data analysis results, because the manufacturer's data did not agree with the fleet's fuel management system data. The manufacturer refined the data analysis to correct these errors after the first year. The Department did not continue using the manufacturer's data and reporting service after the first year because of the high subscription cost and uncertainty of the data analysis results' accuracy. However, Energy Xtreme agreed to continue analyzing the data to calculate the system performance and benefit at no cost. The fleet downloaded data and submitted results to Energy Xtreme for the next two years. The fleet identified issues with the data analysis results and asked Energy Xtreme to review the analysis process. Energy Xtreme re-analyzed the Department's dataset using a refined analysis methodology. The revised results were different and showed less system usage and benefits than the original results. This concerned the fleet and led to a lack of trust that the data results were accurate and reliable. The Department did not share robust performance and cost data, but it did state that it has not continued to use the IRT technology because of the short battery run time, short battery life, and idle reduction performance that would not result in a reasonable payback for future Department-funded systems.

\section{City of Dallas Police Department (Police, Using Lead-Acid Battery APU)}

The City of Dallas Police Department installed Energy Xtreme battery APU systems on six Ford E-series paddy wagon vans (Figure 5) that entered service between 2007 and 2008, using U.S. Department of Energy grant funding obtained via the North Central Texas Council of Governments. Since grant funds paid for the systems, system payback was not a primary metric, but understanding the system's cost-effectiveness for projecting payback for potential future Department-funded systems was a project goal. When the

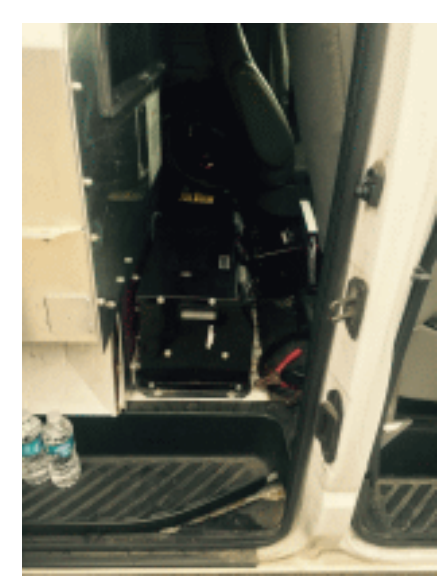

Figure 5: Battery system installed behind front seats of paddy wagon van. Courtesy of City of Dallas. 
fleet was interviewed, all of the systems had had their batteries replaced once and five of the six systems were not functional. The fleet stated that its system performance dataset was not robust. The fleet stated that two years of data may have been collected by the APU manufacturer, but the City of Dallas Police Department has no good way of capturing and analyzing the data on its own.

\section{County of Santa Barbara Sheriff's Office (Police, Using Managed Engine Stop/Start)}

The County of Santa Barbara Sheriff's Office installed the Havis IdleGuard2 system on all 55 of the Department's cruisers. These vehicles are the Department's only high-idle vehicles. The IdleGuard2-equipped vehicles have been operational since September 2014 (i.e., for 11 months).The system's petroleum reduction performance varies by Sheriff's station because of variations in the type of operation performed by each station.

The hardware cost for the complete IRT system was $\$ 380$. The conventional deep-cycle starter battery was used; no additional battery was installed. The systems were installed by County mechanics, each in about four hours. The mechanics' labor cost was not directly factored into the total system cost, since it did not increase the County's labor costs. The system manufacturer does not make claims regarding the petroleum savings or payback period, since the duty cycle (percent idle and daily idle time) and fuel cost are very fleet-specific. Santa Barbara County determines its fuel consumption performance on the basis of improved fuel economy. Fuel economy improvement has ranged between $7.5 \%$ and $22 \%$; with a fleetwide average of $9.8 \%$ improvement. The fleet, with 55 cruisers, projected a 14,230-gallon annual fleetwide savings, or a per-car savings of 259 gallons per year. At an average fuel cost of $\$ 3.00$ per gallon, payback is achieved after 127 gallons have been saved. This savings is achieved, on average, in approximately 5.9 months ( 0.5 years).

Similarly to the rest of the vehicle's mobile data systems, the fleet anticipates using the IRT system hardware on 2 or 3 vehicles before it is replaced. This is essentially the re-chassis approach used by fire and ambulance fleets. This approach also increases the return on investment. The systems could potentially still be used past this point, but normal wear and tear, and the availability of newer technology with improved features and lower cost, limit the usefulness of extending the re-chassis approach for too long.

\section{U.S. Border Patrol (Police, Using Lithium-Ion Battery APU)}

The U.S. Border Patrol patrols the country's northern and southern borders. The fleet interviewed for the case study operates in Arizona. The fleet operates in hard and hot environments, and travel is frequently offroad, so pickup trucks and sport utility vehicles are used instead of typical police sedans. Patrol vehicles include one Chevy Tahoe, one Chevy Silverado, and one Ford F-150 canine patrol unit. A baseline police equipment-equipped vehicle costs approximately $\$ 40,000$.

The U.S. Border Patrol has three primary vehicle duty type classifications:

1. Overwatch - Officers drive to the location to be monitored and remain stationary all day long (unless they are responding to a situation). The vehicles are idled through the whole shift (approximately 8 hours) to provide power to equipment and HVAC. The long idle time requires a large-energycapacity battery pack. The vehicles are used for all three shifts per day, so the daily idling approaches 24 hours.

2. Typical Law Enforcement - This type of duty cycle is roughly $50 \%$ idling and $50 \%$ driving. There is less idling, so this cycle requires a smaller-capacity battery (lower-cost system).

3. Supervisor/Administrative - These vehicles are used mostly for driving between locations. They have very low idling times, so these vehicles are not good candidates for IRT. 
The heat soak in the immediate area around the idling vehicle increases the heat infiltration rate into the passenger cabin and the resulting load on the vehicle's air-conditioning system. This factor is increased because the fleet operates in the hot southern U.S. The U.S. Border Patrol began using three pilot ZeroRPM lithium-ion battery APU-equipped vehicles (one each of the above-mentioned models) for overwatch duty in February 2014. The installed system (Figures 6 and 7) costs between $\$ 10,000$ and $\$ 15,000$ and saves one gallon of fuel per hour of avoided idling. The overwatch application was selected because it has the highest amount of per-shift and annual idling, would test the system the most, and would lead to the highest annual savings. The APU model used for this application has a battery run time of approximately four hours.

The U.S. Border Patrol currently uses only fuel-cost savings to calculate payback or return on investment. The fleet keeps its vehicles for 6-8 years, but the agency's policies require that the IRT systems have a payback period of $\leq 18$ months. The IRT-equipped overwatch vehicles are expected to reach payback in less than one year. The vehicles have been in use for roughly 1.5 years, but the fleet has not done a robust performance and cost data analysis. The initial results with the three pilot vehicles were positive, so the U.S. Border Patrol is purchasing an additional 114 units. The systems include two models/versions, one with three batteries (for overwatch duties, providing roughly 4 hours of run time) and one with two batteries (for typical law enforcement duties, providing roughly 2.5 hours of run time). The smaller system is less expensive because it has fewer battery packs. U.S. Border Patrol fleets along the northern borders may not require the electric HVAC system, which would reduce the system cost.
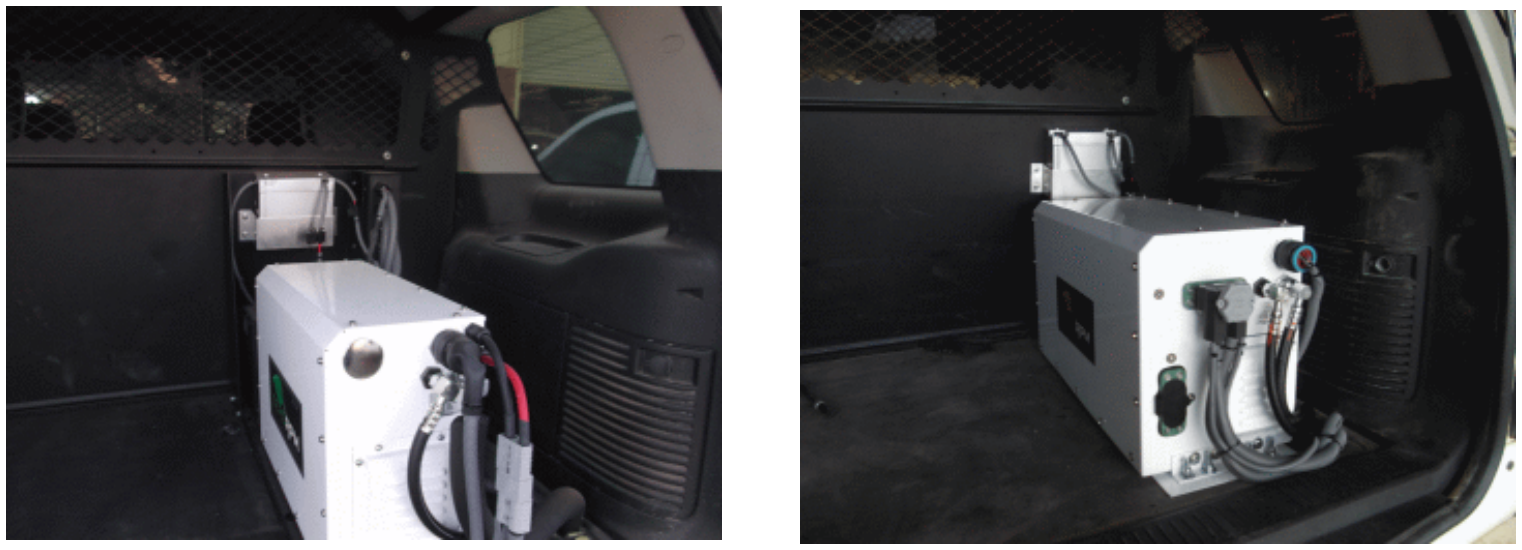

Figure 6: ZeroRPM IMS 60 (left) and IMS 100 (right) installed in load area of Chevrolet Tahoe. Courtesy of U.S. Border Patrol.

The key ZeroRPM system function is to reduce engine operating hours. The fleet will determine if it can perform vehicle maintenance on the basis of accumulated engine hours, not miles, to reduce the preventative maintenance costs. Any additional cost savings from reduced maintenance costs will be included in the payback calculations once fleet management has robust data to support it. The fleet will also evaluate whether the decreased engine wear results in longer vehicle life. The U.S. Border Patrol replaces its vehicles when the total maintenance cost (over the vehicle lifetime) reaches $55 \%$ of the original total vehicle cost, so reducing maintenance has

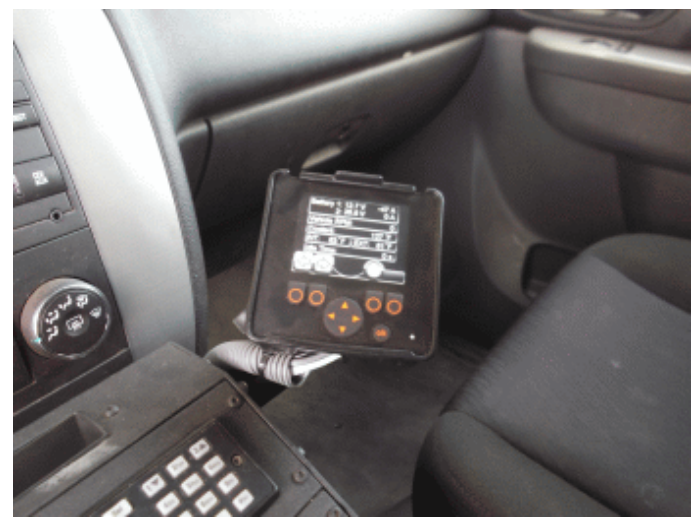

Figure 7: ZeroRPM user interface screen. Courtesy of U.S. Border Patrol. the potential to increase vehicle life. 


\section{Tuscaloosa Police Department (Police, Using Lithium-Ion Battery APU)}

Tuscaloosa Police Department conventional canine patrol vehicles run the engine all day long to keep the dog comfortable and safe. Each vehicle operates for one 8- to 10-hour shift per day, five days a week. This equates to $40-50$ engine hours per week. The vehicle is stationary (i.e., idling) much of this time. The heat rejected from the idling vehicle (engine cooling system, underhood heat radiation, air-conditioning system, and exhaust system) causes the immediate area around the vehicle to be much warmer than the ambient environment. This higher local ambient temperature increases the heat infiltration rate into the passenger cabin and increases the load on the vehicle's air-conditioning system. This operational factor is increased for the Tuscaloosa Police Department because the fleet operates in the hot and humid southern U.S.

The Department had equipped four Chevrolet Tahoe canine patrol units with ZeroRPM lithium-ion battery APU IRT systems by early 2012 (approximately 3.5 years of use). The Tuscaloosa Police Department's system includes electric air-conditioning, but does not include heat (which is not typically needed in this area). The baseline police canine equipment-equipped vehicle costs approximately $\$ 50,000$. The fleet keeps its vehicles between 6 and 7 years. The ZeroRPM installed system cost approximately $\$ 10,000$. (The fleet noted that it was ZeroRPM's first commercial customer, so the system cost may not be representative of current systems.) ZeroRPM did not provide a fleet-specific savings estimate. ZeroRPM estimated 3.5 hours of battery run time (based on an average police vehicle electrical load). The fleet observed run times between 2.0 and 2.5 hours per full charge, on average. These run times were less than the fleet expected, but the vehicle's electrical loads (e.g., air-conditioning because of the hot environment) were higher than estimated. A larger battery would address this issue, but at higher cost. The ZeroRPM telematics system collects system performance data. The Tuscaloosa Police Department does not receive these data, and has not done any other data analysis to quantify the system's fuel savings performance. Even so, the fleet is pleased with the system performance.

\section{Lessons Learned and Future Plans}

\section{Lessons Learned}

Each fleet's experience was unique; however, using a single generation of a single fully developed IRT seemed to be the best approach for ensuring driver acceptance and minimizing training and confusion on how the systems operate. Physically smaller, lighter-weight, and lower-cost battery APU systems with longer battery run times and useful lifetimes are needed to accelerate adoption. This is true for both lead-acid and lithiumion battery systems, and it is especially true for police cruisers, which have less available space and consume less fuel annually than larger vehicles (e.g., ambulances).

\section{Robust Data Acquisition and Analysis}

Data collection and analysis were common issues among many of the fleets in this study. Fleets were not collecting (or able to collect) information that enabled them to understand the baseline operation of their vehicles well enough to allow the IRT system to be properly sized. Fleets also noted the lack of a robust analysis of in-use performance of these systems (fuel and maintenance savings estimates). This analysis is critical for understanding how the technology performed and for determining the system's payback period, return on investment, and/or annual petroleum/monetary savings (the applicable metric[s] vary by fleet). Without the requisite data to understand fleet operations and the benefits of new technologies, it is difficult or impossible for fleets to justify the investments necessary to deploy IRT. 


\section{System Sizing (Battery APU)}

Several fleets indicated that improper battery sizing/capacity/capability was a common issue. This difficulty typically resulted from not knowing (or measuring) the electrical loads that the battery APU system would have to power. Because these loads were not known, the manufacturer's battery run time estimates were accepted as fact. This pitfall can be avoided by measuring the vehicle's electrical load while idling and then using this information to determine the battery capacity needed to achieve the required battery run time. The result will likely point to the need for a higher battery capacity, and thus a higher initial system cost. The effect on battery useful life will have to be evaluated because higher battery capacity will result in slower cycling, which improves useful life.

\section{Poulsbo Fire Department (Fire, Using Diesel APU, and Ambulance, Using Lead-Acid Battery} APU)

For safety reasons, the Poulsbo Fire Department did not want the first-generation systems to be automated (there were concerns about the engine starting unexpectedly, resulting in staff/patient injuries). Experience alleviated this concern, and all new systems are automated to maximize fuel savings. The Poulsbo Fire Department actively worked with the IRT system developer to develop and refine the system. As a result, vehicles are equipped with different generations of systems. This variation increased driver/maintenance training requirements and increased user confusion about how each system works. The fleet expects that driver acceptance will improve once all trucks are equipped with the final system version.

\section{U.S. Air Force (Fire, Using Diesel APU)}

The U.S. Air Force stressed that it is important to make sure the IRT system is foolproof and does not have a user switch to disable the system.

Austin-Travis County Emergency Medical Service (Ambulance, Using Lead-Acid Battery APU) The Austin-Travis County EMS expects that driver acceptance of the Stealth Power lead-acid battery APUs will improve once all ambulances are using the same version of the system. Fleet management also stressed that the system needs to add a battery APU system bypass so that the ambulance works even if the APS system is down.

\section{Vermont Department of Environmental Conservation (Ambulance, Using EPS)}

In general, the Vermont DEC has found that the seven MediDock kiosks installed through this program are sufficient for the ambulance services at those hospitals.

\section{Raleigh Police Department (Police, Using Lead-Acid Battery APU)}

The IRT manufacturer (Energy Xtreme) offered the Raleigh Police Department a data monitoring and reporting service (\$300 to 400/car-year). The Department questioned the system usage and savings results. The manufacturer updated its calculations several times in the second and third years, and each update reduced the estimated savings. The data and analysis results issues and the high cost led to the fleet discontinuing the service after Year 1. Raleigh determined through this project that the IRT system weight and its potential impact on vehicle driving performance must be addressed. Drivers complained that the battery APU-equipped cars were not handling properly/safely. To resolve the problem, the spare tire and batteries were relocated in the trunk to improve the balance and handling. All 29 IRT-equipped cars were also retrofitted with coil-over rear shocks ( $\$ 200-300$ plus 1-2 hours labor for installation on each car). The modified cars were track-tested to verify that the performance was acceptable. 


\section{City of Dallas Police Department (Police, Using Lead-Acid Battery APU)}

The City of Dallas Police Department commented that the Energy Xtreme lead-acid battery system is too large. There was not enough room in the trunks of police cruisers (the initial fleet application) for the battery APU system and all of the police gear. As a result, the systems were installed only on paddy wagon vans. The fleet stated that the system needs to be small enough to fit in the trunks of cruisers.

\section{County of Santa Barbara Sheriff's Office (Police, Using Managed Engine Stop/Start)}

The County stressed that it is critical to not opt for vehicle-manufacturer-installed auto engine start because it conflicts with the Havis IdleRight 2 system. The IRT system has an inexpensive workaround add-on device to address this problem if needed. Officers liked having the added convenience of keyless entry to the interior and trunk (not available on standard cruisers). This entry mode helped ease the transition/adoption because it gave them a new convenience feature unique to the IRT vehicles.

\section{U.S. Border Patrol (Police, Using Lithium-Ion Battery APU)}

The U.S. Border Patrol initially used miles-per-gallon improvement as the performance comparison metric for evaluating the system performance and payback. Initial data analysis results using this metric were not consistent because the vehicle miles traveled for some vehicles decreased at the same time as fuel consumption decreased, owing to changes in usage patterns. The fleet determined that the miles-per-gallon metric was too subjective and variable, and decided to change the metric to engine hours per gallon of fuel used.

\section{Tuscaloosa Police Department (Police, Using Lithium-Ion Battery APU)}

The fleet stressed that the ZeroRPM system needs to be installed before the vehicle is upfitted for police duty, especially for canine unit use. The system installer routes the electric cables, signal cables, and HVAC coolant lines inside the passenger cell (so these are not exposed to the external environment). Installing the system after the canine and police hardware is installed would require removing interior body panels and the upfit equipment. This process would be labor-intensive and much more complicated than if the system were installed in a new, unmodified vehicle.

The canine unit's dog box occupies approximately $2 / 3$ of the rear seat and $50 \%$ of the cargo area to give the dog enough space to be comfortable. The dimensions of the ZeroRPM system are approximately 12 " wide $\mathrm{x}$ 20 " deep x 15" tall, so it takes up a lot of the remaining cargo area.

\section{Future Plans}

In general, fleets whose experience has been positive, regardless of technology, plan to continue deploying and using IRT. In general, fleets with less positive experience did not have plans to continue IRT use.

\section{Poulsbo Fire Department (Fire/Ambulance)}

The IRT system's performance and cost meets Poulsbo Fire Department's needs. There are currently Washington State funds available that pay for $100 \%$ of the system cost for government-owned/operated fire, ambulance, and police fleets. So all new fire trucks and ambulances will continue to use the same systems too.

\section{U.S. Air Force (Fire)}

The U.S. Air Force plans to continue using the diesel APU system, obtained from any manufacturer that can meet the performance specification, for new truck purchases. The U.S. Air Force is interested in considering retrofitting in-service trucks, but the per-vehicle cost will be roughly between $\$ 15,000$ and $\$ 20,000$. The high cost is due to the complexity of adding new controllers/functionality and the added need to replace the 
HVAC system with an electrically powered system on an existing vehicle. The much higher cost and shorter post-retrofit vehicle useful life for retrofits make the cost-effectiveness uncertain. Therefore, retrofits are only an option if external grant funding is available. The U.S. Air Force is also investigating pure battery APUs, but feels the technology is earlier in its development phase, so there are not enough testing results to warrant further interest at this point.

\section{Austin-Travis County Emergency Medical Service (Ambulance)}

The Austin-Travis County EMS stated that battery APUs have replaced combustion engine APUs, so any replacement system would be a battery APU system. The fleet is pleased with its current IRT system. Grantfunding is not required for new vehicles; however, it would likely be required for retrofits to make the business case favorable. The fleet is investigating grant funding for both retrofits and new vehicles.

\section{County of Santa Barbara Sheriff's Office (Police)}

The County's entire sheriff cruiser fleet was equipped with the Havis IdleRight 2 IRT in the program described in the case study. No other County vehicles have duty cycles with a high percentage of idle, so there is no need or plan to expand IRT use elsewhere in the fleet.

\section{U.S. Border Patrol (Police)}

The U.S. Border Patrol is pleased with the ZeroRPM lithium-ion battery APU systems and plans to continue deploying them across the fleet. The national fleet is separated into several regional "sectors," and each sector is separated into smaller "stations." The fleet's plan is to first equip the IRT candidate vehicles at the station with the highest idle percentage with the ZeroRPM system. The combined savings from this station will be used to deploy systems on IRT candidate vehicles at other stations, and the overall combined savings will be used to deploy systems across a whole sector. The process will continue, starting in the next-highest idle sector, until all of the IRT candidate vehicles are equipped. ZeroRPM is doing all of the installations for the current group purchase. The fleet plans to be trained to perform future installations, because this approach will save it approximately $\$ 2,000$ per system.

\section{Tuscaloosa Police Department (Police)}

The fleet plans to deploy more ZeroRPM lithium-ion battery APU systems if town funds can be allocated for their purchase.

\section{Other Observations}

For many of the interviewed fleets, IRT systems purchased as a new-vehicle option were covered by "fleet modernization" funds. These funds came from a different source than funds required to retrofit existing vehicles.

"Re-chassising" occurs when upfitted vehicle equipment items, including the intact fire or ambulance box and IRT, are moved to a new chassis at the original chassis' end-of-life. This is an option for extending the IRT systems' useful life and increasing the return on investment. Several of the interviewed fleets (Santa Barbara County Sheriffs Office, Poulsbo Fire Department, and Austin-Travis County EMS) plan to re-chassis several types of IRT to extend the system life and to increase their return on investment. As noted earlier, depending on the system type, additional costs may be required to reprogram the systems to properly operate on the new vehicles.

Exhaust temperature during idling is low, so the diesel particulate filter (DPF) is not passively regenerated as it would be while driving normally. In this case, the DPF must be actively regenerated at high temperatures, 
which decreases the DPF catalyst life. Several fleets mentioned that the reduced engine idling may extend DPF maintenance intervals and DPF catalyst life. The impact on lifetime DPF system maintenance and replacement costs has not been quantified by any of the interviewed fleets. However, eliminating DPF cleanings and/or DPF catalyst replacements has the potential to significantly increase the cost savings over the vehicle lifetime. Once quantified, the changes in DPF maintenance and replacement frequency due to reduced engine hours need to be included in fleets' payback calculations.

\section{Conclusions}

A range of IRTs is available for, and being used by, emergency service vehicles including police vehicles, ambulances, and fire trucks. The available IRTs include combustion engine (i.e., diesel or gasoline) APUs, battery APUs, systems that manage engine operation to turn it off after a certain time threshold, and EPSs.

\section{Battery APU}

Battery APUs are a good fit for idling applications that primarily need electric power to run electric equipment while the vehicle is stationary. Electric air-conditioning and heat (using coolant circulation) is also possible with these systems, but requires much higher battery capacity (and cost). Among the interviewed fleets, battery APUs were the most prevalent option selected by police (cruisers and other vehicle types) and ambulance fleets. No fire trucks used battery APU technology.

\section{Combustion Engine APU}

Diesel combustion engine APUs represented all of the IRT used by the interviewed fire truck fleets. This approach provides up to the maximum output power for very long times (limited only by the diesel fuel supply). This duration is necessary, since the trucks may be on scene for long periods. A battery APU would not provide the same level of function. For fleets that have manually controlled diesel APUs as standard equipment, the incremental cost of the automatically controlled systems is very low $(\sim \$ 3,000)$. For fleets that do not, the cost of adding the automatically controlled diesel APU IRT is high $(\$ 30,000)$. Ambulance and police vehicles did not use this type of APU, owing partly to the available space and the lack of need for longterm continuous power. These APUs provide the required power $(5-8 \mathrm{~kW}$ continuous) while the trucks are stationary (and when the water pump is not in use). If a manually controlled APU is included in the baseline vehicle specification, the additional hardware and expense of an automatically controlled system is relatively minor. This leads to a quick return on investment.

The APU uses approximately $80 \%$ less fuel than the main engine during these periods. Another benefit is that the APU uses fuel from the same fuel tank as the main engine. This essentially allows continuous use. One fire truck fleet stated that it was interested in battery APUs, but indicated that that the technology was not proven enough for fire service use. The limited time available during the truck duty cycle to recharge batteries will also likely be an adoption barrier.

\section{Electrified Parking Space}

The EPS approach offers several pros and cons for ambulance applications. The benefits include the following: 1) Focused idling reduction/exhaust emissions reduction occurs at the hospital, where ambulance idling is most concentrated and can have the most serious impacts, 2) the kiosks can be used by all ambulances visiting a hospital, even if they do not regularly serve EPS-equipped hospitals, 3) there is no need to install a system on each ambulance to ensure the ability to eliminate idling (important for volunteer ambulance companies and towns with tight budgets), and 4) there is no downtime for the ambulance service providers for installing hardware. Challenges include the following: 1) system use is determined by the driver 
(personal preference, company anti-idling policies, etc.), and 2) driver compliance requires monitoring by hospital staff and/or ambulance company staff.

\section{Managed Engine Stop/Start}

Several manufacturers offer systems of this type in the IRT category. Only one fleet was interviewed that used this IRT approach. This fleet's comments on performance and payback were very positive because of the system's low capital cost and the fact that the installation could be done by staff mechanics. 


\section{Supplemental Information}

This section provides additional relevant and potentially useful information learned from the fleets that did not directly address the previous section topics.

\section{U.S. Air Force Diesel APU IRT Vehicle Procurement Specification Language}

The U.S. Air Force provided the specification listed in its "Commercial Item Descriptions" for fire trucks equipped with IRT, as an information source for the Clean Cities program and to be shared with other fleets:

"An IRT system shall be supplied with the apparatus that shall shut down the main chassis diesel engine during operations not requiring it. This system shall be automated and shall not require intervention from the vehicle operator. The chassis voltage system shall be protected against extreme drain of the battery bank. If the vehicle's voltage drops too low, the automatic engine controls shall start the chassis diesel engine to provide a charge. The IRT system shall power an in cab climate control system with a minimum of 13,500 BTU air-conditioner evaporator, 300 CFM air flow, and 5,600 BTU heating element. The IRT system shall be available when the chassis air brake is set and when the power take-off device is not engaged. The system shall interface with the chassis batteries and an auto-eject electric shoreline connection. Easy to access control panel(s) and fuse boxes shall be installed on the vehicle. The fuel supply for the IRT shall be the chassis fuel tank. At a minimum the following systems shall be operable when the IRT is engaged: in cab climate control system, radios, DOT truck lighting, NFPA required emergency lights, step lights and compartment lights."

\section{Fleet-Specific IRT System and Fleet Details}

\section{Poulsbo Fire Department (Ambullance, Using Battery APU)}

The Department found that industry did not have what the Fire Service needed, so the Department developed, tested, and refined a custom system in collaboration with Cummins Northwest. The system uses a battery pack comprised of two 85-Ah Optima deep-cycle batteries. To minimize power demand, vehicle lighting must use light-emitting diode (LED)-type lights. (Washington State was an early LED light adopter, so this was not a change.) Air-conditioning is not needed in the Seattle, Washington, area. (Cummins Northwest is identifying a 12 VDC air-conditioning system for fleets that need it.) Heating is needed, so a diesel fuel heater is used to provide heat for the drivers' and patients' cabins. The system shuts the main engine off after three minutes. The system provides electrical power for between 6 and 8 hours on a full charge.

The installed system cost is $\$ 12,000$ (this is $5 \%$ of the total medic unit cost of $\$ 240,000$ ). John Lightner (Cummins Northwest) and Jim Gillard (Poulsbo Fire Department) got a bill introduced/passed that allocates funds that offset $100 \%$ of the purchase and installation costs of IRT systems for governmentowned/operated fire and police fleets. ${ }^{2}$ Thus, the systems were completely grant-funded. (The resulting law also provides low-interest loans for private/volunteer fire and police fleets to purchase and install IRT systems.) Cummins Northwest won the bid to be the battery APU IRT supplier for all Washington State fire departments. The Department does not have an expectation for the system's useful life. Several systems are four years old and are operating with the original batteries. The medic unit boxes will be re-chassised (i.e., the whole box, including the battery APU, will be moved to a new chassis) at the end of the chassis' life.

2 State of Washington, House Bill 2569, 2013-2014 Session, “Act Relating to Reducing Air Pollution Associated with Diesel Emissions," http://apps.leg.wa.gov/documents/billdocs/201314/Pdf/Bills/House\%20Passed\%20Legislature/2569-S2.PL.pdf. 


\section{Poulsbo Fire Department (Fire, Using Diesel APU)}

The Department found that industry did not have what the Fire Service needed, so the Department developed, tested, and refined a custom system in collaboration with Cummins Northwest. The Department's fire trucks previously used portable gensets that were secured to the truck to provide on-scene power. They were not integrated and did not meet the strictest emissions standards (Tier 4). The custom system developed by Cummins Northwest uses a Tier 4, 4.5-kW Onan diesel APU. The generator has quick-disconnects for the fuel and electrical connections to allow for fast-swapping and/or moving the generator. The system turns the main engine off after three minutes. This allows the system to know the vehicle will be stationary for awhile and provides enough time to warm up the generator APU engine oil. The APU generator solely powers two 80-A battery chargers that maintain the charge on the truck's house batteries. All vehicle electrical loads are powered directly from the batteries. To minimize power demand, vehicle lighting must use LED lights. (Washington State was an early LED light adopter, so this was not a change.) The APU is fueled from the main vehicle fuel tank. If the main tank is full, the system can provide on-scene power for 150 hours. The generator is installed in a channel on top of the truck, so most noise is reflected up. The result is a much lower noise level than with the main engine idling. This is significant because it enables much better communication between staff and patients. This improved communication significantly improves scene safety. Fire trucks' APUs can also be used to charge the Department's battery APU-equipped ambulances while on scene once their batteries are discharged.

The installed system cost is $\$ 30,000$ (this is $0.03-5.4 \%$ of the roughly $\$ 550,000$ to over $\$ 1$ million truck cost). John Lightner (Cummins Northwest) and Jim Gillard (Poulsbo Fire Department) got a bill introduced/passed that allocates funds that offset $100 \%$ of the purchase and installation costs of IRT systems for governmentowned/operated fire and police fleets. Thus, the systems were completely grant-funded. (The resulting law also provides low-interest loans for private/volunteer fire and police fleets to purchase and install IRT systems.) Cummins Northwest won the bid to be the diesel APU IRT supplier for all Washington State fire departments. The fire truck boxes/systems will be re-chassised (i.e., the whole box, including the diesel APU, will be moved to a new chassis) at the end of the chassis' life.

\section{United States Air Force (Fire, Using Diesel APU)}

The U.S. Air Force uses diesel APU systems from several manufacturers on its fire truck vehicles (e.g., pumpers, rescue trucks, water tankers, and hazmat vehicles). The systems must meet the U.S. Air Force's performance specification (see above in the Supplemental Information section under "U.S. Air Force Diesel APU IRT Vehicle Procurement Specification Language"), so all systems function similarly. The control system engages the diesel APU after two minutes of engine idling when the service brake is pulled/engaged. The APU provides $8.0 \mathrm{~kW}$, which is sufficient for powering the LED emergency lights, LED interior lights, cabin HVAC, and the onboard electronic equipment (computers, etc.). The manufacturer of the truck or IRT system does not matter to the U.S. Air Force. (Using multiple providers does increase training needs.) The diesel APU system can be applied both to new trucks and as a retrofit to in-service trucks. The incremental system cost for a new truck is approximately $\$ 3,000$ above a standard manually controlled fire truck APU system. This low capital cost results in a favorable payback period.

The incremental system cost for an in-service truck is estimated to be approximately $\$ 15,000$ to $\$ 20,000$. The high capital cost will likely prevent retrofits from achieving payback. Therefore, the U.S. Air Force is only installing the diesel APU system on new vehicles at this time.

The U.S. Air Force recognized the AFCEC Fire Emergency Services Branch as the "Innovator of the Quarter" for the first quarter of 2015 for its market research and collaboration with fire vehicle 
manufacturers to develop, and commercially offer, an integrated IRT system that cost-effectively and significantly reduces diesel fuel use while vehicles are stationary.

Austin-Travis County Emergency Medical Service (Ambulance, Using Lead-Acid Battery APU) Austin-Travis County EMS operates two sub-fleets (79 total vehicles). The first sub-fleet, the Austin City EMS fleet, experiences high daily calls, usage, and idling. The second sub-fleet is the Austin-Travis County EMS (County) fleet, which operates outside the city limits. This sub-fleet experiences much lower use (1-3 calls per day is typical).

Austin-Travis County EMS worked together with Stealth Power to develop the ambulance system. (The Austin-Travis County EMS uses the Model EMS6, which has a 6.0-kWh energy capacity battery pack and a 200-A, 12 VDC/120 VDC output. This system weighs between 375 and $500 \mathrm{lb}$. The system is based on Stealth Power's 1.0-kWh system for police vehicles, but is more complicated because of the level of body, electrical, and control integration required for an ambulance. The system operates all day long to power all electrical devices on the vehicle, regardless of whether the vehicle is parked or moving. The battery pack is charged either with an AC-powered shorepower connection or by the vehicle's alternator while moving (if needed). The fully charged battery pack provides between 3.0 and 3.5 hours of run time.

The installed system cost is between $\$ 20,000$ and $\$ 25,000$. Stealth Power estimates a battery life of between 3 and 5 years. Austin-Travis County EMS has added 27 Stealth Power lead-acid battery APU-equipped ambulances to its fleet between 2011 and 2015. Many of the fleet's battery APU-equipped ambulances have been operating for three years on the original battery pack. The $6.0-\mathrm{kWh}$ battery pack costs roughly $\$ 7,500$ to replace. All systems to date have been installed on new vehicles. The system installations were done at/by the ambulance body manufacturer when the ambulance box was installed on the chassis. New vehicles are purchased with regular fleet modernization/replacement funds, so grant funding has not been used, and is not required.

\section{Vermont Department of Environmental Conservation (Ambulance, Using EPS)}

The Vermont DEC investigated options for reducing ambulance idling emissions at hospitals. The organization considered APUs, but decided instead to fund the installation of shorepower-type electrification kiosks at the hospitals. Although an ambulance may idle while away from the hospital and additional air quality benefits could be provided by having an APU on the ambulance at all times, having an IRT kiosk at the hospital still provides protection to the sensitive population at the hospital, which is another goal of the grant-funded program. Additional factors that influenced Vermont DEC's technology selection included the following:

- A one-time installation and one piece of equipment to maintain;

- No need to make alterations to multiple ambulances, and no downtime for the ambulance service providers;

- Most hospitals have multiple ambulance service providers (some providers are volunteer organizations funded by towns and town budgets), and having the hospital install the IRT decreased the complexity of the project, especially when a cost match was required; and

- The kiosks can be used by all ambulances visiting a hospital, even if they do not regularly serve the EPS-equipped hospital.

The Vermont DEC funded the installation of seven EPS kiosks at three Vermont hospitals, listed below, between 2011 and 2013. The MediDock kiosk was selected because at the time of the projects, the product was suitable for hospitals, providing both HVAC and power. 
- 2011 - Brattleboro Memorial Hospital (2 kiosks)

- $\quad \underline{2012}$ - Porter Medical Center (2 kiosks)

- 2013 - Rutland Regional Medical Center (3 kiosks)

For the installations where data were available, the installed system cost ranged from $\$ 40,000$ to $\$ 65,000$ per project. This equates to approximately $\$ 14,000$ to $\$ 19,000$ per installed kiosk.

\section{Raleigh Police Department (Police, Using Battery APU)}

The Raleigh Police Department installed 29 Energy Xtreme 2.0-kWh systems in its police cruisers. The systems were all operational by early 2012. The system hardware cost $\$ 3,995$. Energy Xtreme trained Raleigh Police Department maintenance technicians for 1 to 2 days to install the systems. The system installations took Raleigh's mechanics between 4 and 8 hours to perform.

\section{City of Dallas Police Department (Police, Using Battery APU)}

The City of Dallas Police Department commented that the Energy Xtreme lead-acid battery system is too large. There was not enough room in the trunk of police cruisers (the initial fleet application) for the battery APU system and all of the police gear. As a result, the systems were installed only on paddy wagon vans. The six police paddy wagons entered service between 2007 and 2008.

The system was designed to also draw power from the vehicle's 12 VDC starter battery. This design led to the starter battery being drawn down and the vehicle being stranded when the system was engaged. The fleet also noted that HVAC functionality would have improved user adoption.

\section{County of Santa Barbara Sheriff's Office (Police, Using Managed Engine Stop/Start)} The County of Santa Barbara Sheriff's Office evaluated several IRT systems before making a decision: 1) Havis IdleRight 2 (selected technology), 2) custom-made system with two deep-cycle batteries with an electrical isolator, and 3) the Energy Xtreme system. The Havis IdleRight 2 system was selected and was initially used on Ford Crown Victoria police cruisers and Chevy Tahoe cruisers. The fleet is transitioning to other vehicle platforms. The Havis IdleRight2 system can be used on any vehicle. The conventional deepcycle starter battery was used; no additional battery was installed. The IdleGuard2 system is paired with a Viper car alarm system that has automatic engine start/stop functionality. (The system's alarm functionality [sound, flashing lights, etc.] can be silenced if desired.) The complete system is very cost-effective ( $\$ 380$ for hardware). System installation is straightforward, and was done by County mechanics in about four hours. The installation requires a mid-level technician to install the first system for each new vehicle platform. The installer develops vehicle-specific installation instructions to allow less experienced (and less costly) maintenance staff to perform the remaining installations. Fleet management agreed that the system's low cost and expected fast payback did not require grant funding, so the units were purchased with internal funds. The fleet's controlled testing and field experience showed that the first engine shutdown lasts between 3.5 and 4.5 hours. The engine restarts once the battery voltage reaches a low-voltage threshold. The vehicle's alternator charges the battery. The system is configured to run the engine for 12 minutes and then turn it off again. The second engine shutdown lasts approximately 2.5 hours. The third and later shutdowns last approximately 2.0 hours. (Note: in practice, vehicles typically do not reach the second automatic restart.) Santa Barbara has a temperate climate, so officers are instructed not to idle to run the vehicle's climate control system (i.e., HVAC). If HVAC (likely an auxiliary electrically-powered system) were used, the system performance would have been degraded (i.e., shorter engine-off periods) because of the higher electrical energy draw. 
The long periods between restarts also imply that starter wear is not compromised. The fleet is collecting data that isolate incremental IdleRight system restart events to verify the hypothesis that the increased starter usage does not increase starter replacements.

\section{U.S. Border Patrol (Police, Using Battery APU)}

In an environment of declining budgets, it is necessary to operate the vehicle fleet more efficiently to reserve funds for other uses. Thus, extending the vehicle life and reducing maintenance, repair, and operations costs are critical.

The U.S. Border Patrol's vehicles are upfitted for police duty by the Federal Prison Industries program (now operating under the trade name UNICOR). UNICOR uses Federal inmates to build products for the Federal government (and other organizations). UNICOR learned about the ZeroRPM system at a trade show and discussed the system with the U.S. Border Patrol. The U.S. Border Patrol was skeptical about battery APU systems, but agreed that a pilot in-service field evaluation was worthwhile. The U.S. Border Patrol requires pilots to be funded by the manufacturer. The U.S. Border Patrol, Arizona region, did a baseline usage/cost analysis of approximately 600 conventional vehicles (e.g., miles, engine hours, and fuel used) to determine the fleet's duty cycle(s). The fleet evaluated both the ZeroRPM and Stealth Power systems. ZeroRPM was chosen because the company was willing to work with the U.S. Border Patrol to meet all of its performance needs. These included typical battery APU functionality items, but also other system design aspects to maintain safety of systems and staff in the extreme duty environments that U.S. Border Patrol vehicles operate in. Approximately $75 \%$ of the fleet's maintenance, repair, and operations budget is for vehicle maintenance and fuel. Fuel costs alone account for $75 \%$ of this expenditure (56\% of the total maintenance, repair, and operations budget). Thus, reducing fuel and maintenance costs are key. U.S. Border Patrol vehicles are kept at the location they are purchased for (i.e., they are not shared/moved throughout the vehicle's life). This enables the vehicles to be custom-configured for a particular location(s)/duty cycle(s).

The ZeroRPM system includes 1) a system controller that monitors the battery voltage, coolant temperature, etc., 2) lithium-ion battery(s) (the number of modules and types [power- or energy-type] varies by application), 3) a DC-powered air-conditioner (if needed), and 4) a DC-powered coolant pump for heat. The system starts the engine to warm the coolant if the temperature drops below a temperature threshold, and the system starts the engine to charge the batteries if they drop below a voltage threshold. The system also starts the engine when the brake pedal is pressed (engine starting takes approximately two seconds). The standard lead-acid starter battery was removed. The ZeroRPM system provides the power to start the vehicle and operate the vehicle's electrical loads. This feature removes some weight, but also eliminates a fleet maintenance item. ZeroRPM warrants its lithium-ion batteries for five years if they are not installed in the engine bay (because of the high temperature).

\section{Tuscaloosa Police Department (Police, Using Battery APU)}

The Tuscaloosa Police Department was ZeroRPM's first fleet. ZeroRPM's factory is approximately 45 minutes away in Jasper, AL. This proximity enables ZeroRPM to install and evaluate prototype hardware and control software to improve performance. It also ensures that the fleet is running the latest system software. 

Argonne

Energy Systems Division

9700 South Cass Avenue, Bldg. 362

Argonne, IL 60439-4854

www.anl.gov

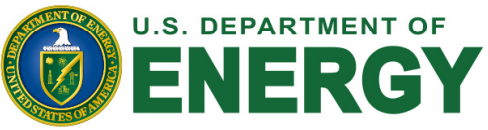

Argonne National Laboratory is a U.S. Department of Energy laboratory managed by UChicago Argonne, LLC 